\title{
A New Species of Andean Gymnophthalmid Lizard (Squamata: Gymnophthalmidae) from the Peruvian Andes, and Resolution of Some Taxonomic Problems
}

\author{
Luis Mamani ${ }^{1,2,3, *(\mathbb{D})}$, Juan C. Chaparro ${ }^{2,3}$, Claudio Correa ${ }^{1}$, Consuelo Alarcón ${ }^{2,3,4} \mathbb{\oplus}$, \\ Cinthya Y. Salas ${ }^{5}\left(\mathbb{D}\right.$ and Alessandro Catenazzi ${ }^{6}(\mathbb{D}$ \\ 1 Departamento de Zoología, Facultad de Ciencias Naturales y Oceanográficas, Universidad de Concepción, \\ Barrio Universitario S/N, Concepción P.O. Box 160-C, Chile; ccorreaq@udec.cl \\ 2 Colección de Herpetología, Museo de Historia Natural de la Universidad Nacional de San Antonio Abad del \\ Cusco (MHNC), Cusco 08000, Peru; jchaparroauza@yahoo.com (J.C.C.); consue.alarcon@gmail.com (C.A.) \\ 3 Museo de Biodiversidad del Perú (MUBI), Cusco 08000, Peru \\ 4 Department of Biology, John Carroll University, Cleveland, OH 44118, USA \\ 5 Área de Herpetología, Museo de Historia Natural de la Universidad Nacional de San Agustín de \\ Arequipa (MUSA), Arequipa 04001, Peru; cinthyasalas84@hotmail.com \\ 6 Department of Biological Sciences, Florida International University, Miami, FL 33199, USA; \\ acatenazzi@gmail.com \\ * Correspondence: luismamanic@gmail.com
}

http://zoobank.org/urn:lsid:zoobank.org:pub:FF0EC17F-965E-410D-AF0A-356B19BD4431 http://zoobank.org/urn:lsid:zoobank.org:act:6B3FCF87-82E4-4E2B-8C3B-99FD93E051CD updates

Received: 23 April 2020; Accepted: 18 September 2020; Published: 21 September 2020

\begin{abstract}
The family Gymnophthalmidae is one of the most speciose lineages of lizards in the Neotropical region. Despite recent phylogenetic studies, the species diversity of this family is unknown and thus, its phylogenetic relationships remain unclear and its taxonomy unstable. We analyzed four mitochondrial (12S, 16S, Cytb, ND4) and one nuclear (c-mos) DNA sequences of Pholidobolus anomalus, Cercosaura manicata boliviana and Cercosaura sp., using the maximum likelihood method to give insights into the phylogenetic relationships of these taxa within Cercosaurinae. Our results suggest that Pholidolus anomalus is nested within the clade of Cercosaura spp., that material we collected near Oxapampa belongs to a new species of Cercosaura, and that lizards identified as Cercosaura manicata boliviana belong to a separate lineage, possibly a new genus. We assign Pholidobolus anomalus to Cercosaura, redescribe the species, and designate a neotype to replace the lost holotype. In addition, we describe the new species of Cercosaura, and comment about the taxonomic status of "Cercosaura manicata boliviana" incertae sedis.
\end{abstract}

Keywords: Cercosaurinae; Cercosaura manicata boliviana; Cusco; diversity; Machupicchu; Oxapampa; Pholidobolus anomalus; Peru

\section{Introduction}

The eastern slopes of the Peruvian Andes are one of the regions with the greatest diversity of flora and fauna [1]. During the last few years, many species of plants and animals from the Peruvian Andes have been discovered (e.g., [2,3]). In particular, researchers have discovered many species of lizards of the family Gymnophthalmidae in poorly explored regions [4-9]. Recent phylogenetic inferences using molecular sequences have uncovered the phylogenetic relationships of many gymnophthalmid taxa [10-13]. However, there are still species whose phylogenetic position remains unclear, such as some populations currently assigned to the genus Cercosaura Wagler, 1830 and Pholidobolus anomalus Müller, 1923. Furthermore, the existence of poorly explored areas in the Peruvian Andes suggests that knowledge of the species richness of this group is still incomplete. 
The genus Cercosaura is composed of 16 species that are widely distributed from the Andes to the Amazon [13-17]. The taxonomy of this lineage has long been confusing, but recent phylogenetic studies based on morphological and molecular data $[11,15,18-20]$ have improved our knowledge of the composition and phylogenetic relationships of Cercosaura. On the basis of a morphological phylogenetic hypothesis, Doan [18] redefined the genus Cercosaura and synonymized it with the genera Pantodactylus and Prionodactylus. This arrangement was subsequently corroborated by molecular studies [19,20]. Later, Doan and Lamar [17] and Echevarría et al. [16] assigned two more gymnophthalmid taxa to the genus Cercosaura, increasing its richness to 14 species. Finally, Sturaro et al. [15] used integrative taxonomy to describe a new species of Cercosaura, and to resurrect C. olivacea. Despite these advances, the position of some species and populations within Cercosaura, such as C. manicata boliviana, remained unresolved.

Pholidobolus anomalus was described by Müller [21] from a single male specimen collected in the Department of Cusco, southeastern Peru. The holotype was deposited in the herpetological collection of the Zoologische Staatssammlung München, Germany (ZSM). Bombings during the Second World War damaged the ZSM collection, causing the loss and destruction of many type specimens, including the holotype of Pholidobolus anomalus [22]. Müller [21] considered the presence of a pair of small prefrontal scales in an almost rudimentary state as an outstanding character for this species. Due to this character, Müller [21] avoided assigning P. anomalus to the genus Placosoma. Instead, on the basis of similarities in pholidosis, he assigned the species to the genus Pholidobolus [21]. In some gymnophthalmid species, the condition of the prefrontal scales is variable at the intraspecific level [23,24]. Since its description in 1923, Pholidobolus anomalus has been reported once in the Department of Cusco [25]. Montanucci [25] analyzed two specimens of $P$. anomalus deposited by Thomas H. Fritts in the herpetological collection at the University of Kansas (KU 134857-58), both collected in the montane forests of Machupicchu (Cusco). On the basis of his morphological observations, Montanucci [25] concluded that P. anomalus was erroneously assigned to Pholidobolus. Generic reallocation of P. anomalus has since been hypothesized by several authors $[25,26]$, but to date no taxonomic change has been proposed.

The molecular phylogenies carried out so far for the genus Pholidobolus included almost all species of the genus (Pholidobolus affinis, P. condor, P. dicrus, P. dolichoderes, P. hillisi, P. macbrydei, P. montium, P. paramuno, P. prefrontalis, $P$. samek, $P$. ulisesi, and P. vertebralis), but not $P$. anomalus because biological material was unavailable $[11,12,27,28]$. Previous authors highlighted the need to obtain new material of this taxon to reassess its taxonomic status and to examine its phylogenetic relationships [11,12,27,29].

In this study, we investigated the phylogenetic relationships of two specimens of P. anomalus, two specimens of Cercosaura manicata boliviana, and a specimen of Cercosaura that we identified as a new species. We analyzed four mitochondrial genes (12S, 16S, ND4, Cytb), and one nuclear gene (c-mos) using maximum likelihood inference. As a result of these analyses, and after examination of external morphology of the material assigned to P. anomalus, we reassign P. anomalus to the genus Cercosaura, provide a new description, and designate a neotype. Additionally, we describe the new species of the genus Cercosaura, and comment on the taxonomic status of Cercosaura manicata boliviana from southern Peru.

\section{Materials and Methods}

\subsection{Biological Material and Taxon Sampling}

We analyzed specimens of Cercosaura and Pholidobolus anomalus from central and southern Peru deposited in the Centro de Ornitología y Biodiversidad, Lima (CORBIDI), Museo de Biodiversidad del Perú, Cusco (MUBI), and Museo de Historia Natural de la Universidad Nacional de San Agustín, Arequipa (MUSA) (Table 1, Appendix A). We examined eight specimens of P. anomalus from Cusco, two specimens of Cercosaura manicata boliviana from Cusco and Puno, and two specimens of Cercosaura pacha sp. nov. from Oxapampa (Figure 1). 


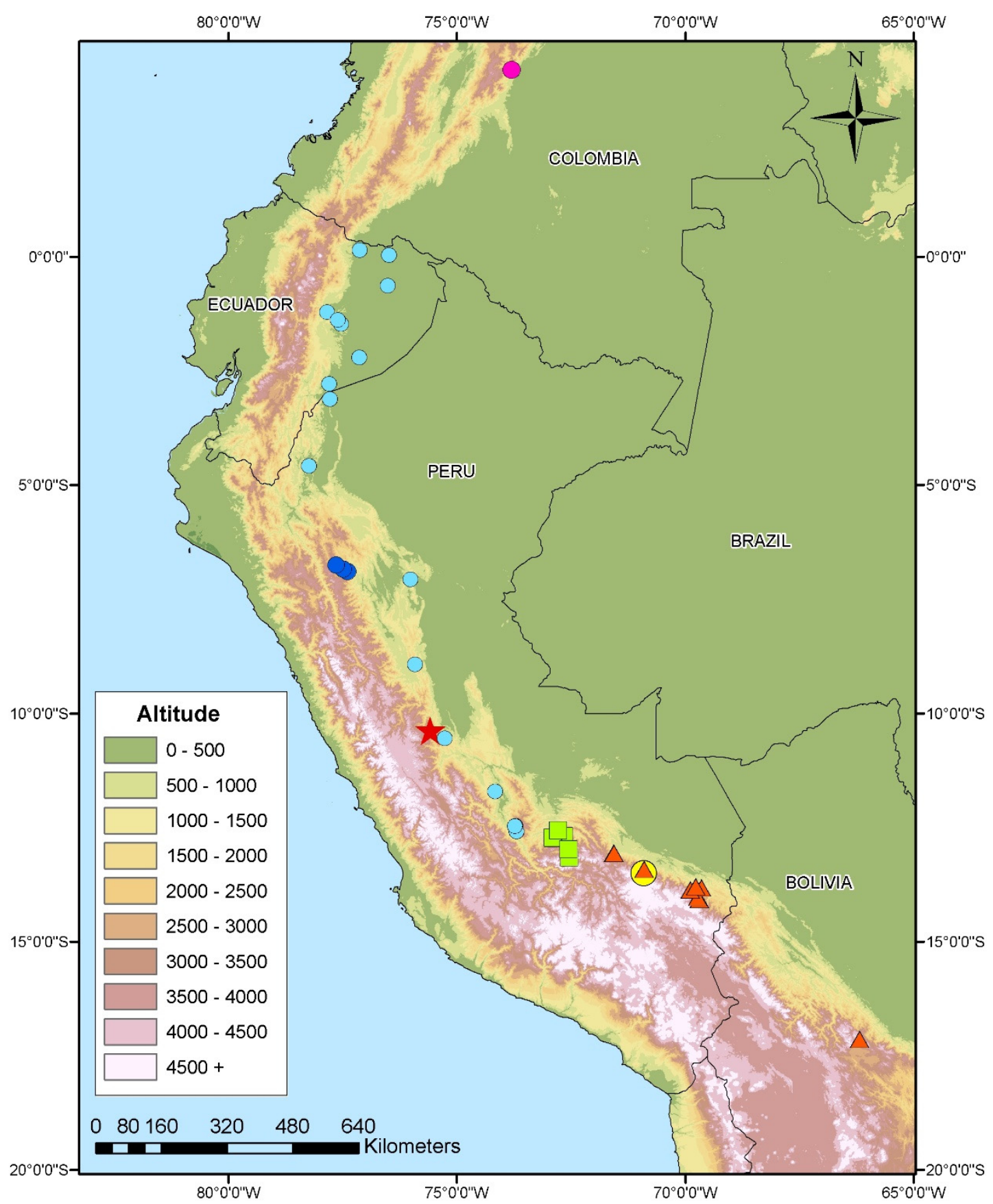

Figure 1. Geographic distribution of species of the genus Cercosaura in the Cordillera de los Andes. Orange triangles = "Cercosaura manicata boliviana"; light-blue circle = C. manicata; purple circle = $C$. hypnoides; blue circle $=C$. doanae; green square $=C$. anomala ; red star $=C$. pacha sp. nov.; yellow circle $=$ Cercosaura sp. Data taken from the literature $[16,17,30]$ and museum records. 
Table 1. Localities (all in Peru), coordinates, voucher numbers, and GenBank accession codes of newly sequenced specimens included in this study. $\left({ }^{*}\right.$ described herein)

\begin{tabular}{|c|c|c|c|c|c|c|c|c|}
\hline Species & Locality & Coordinates & Voucher & $12 S$ & $16 S$ & ND4 & Cytb & c-mos \\
\hline $\begin{array}{l}\text { Pholidobolus } \\
\text { anomalus }\end{array}$ & $\begin{array}{l}\text { Tucantinas, } \\
\text { La Convención, } \\
\text { Cusco }\end{array}$ & $\begin{array}{c}12^{\circ} 44^{\prime} 16^{\prime \prime} \\
\mathrm{S} / 72^{\circ} 53^{\prime} 29^{\prime \prime} \mathrm{W}\end{array}$ & MUBI 13328 & MT531384 & MT524454 & MT522845 & - & MT512508 \\
\hline $\begin{array}{l}\text { Pholidobolus } \\
\text { anomalus }\end{array}$ & $\begin{array}{c}\text { Urusayhua, } \\
\text { La Convención, } \\
\text { Cusco }\end{array}$ & $\begin{array}{c}12^{\circ} 41^{\prime} 32^{\prime \prime} \\
\mathrm{S} / 72^{\circ} 39^{\prime} 18^{\prime \prime} \mathrm{W}\end{array}$ & MUBI 13626 & MT531385 & MT524455 & MT522846 & MT512513 & MT512509 \\
\hline $\begin{array}{l}\text { Cercosaura } \\
\text { manicata } \\
\text { boliviana }\end{array}$ & $\begin{array}{c}\text { San Pedro, } \\
\text { Parque nacional } \\
\text { del Manu, } \\
\text { Paucartambo, } \\
\text { Cusco }\end{array}$ & $\begin{array}{c}13^{\circ} 4^{\prime} 4^{\prime \prime} \\
\mathrm{S} / 71^{\circ} 33^{\prime} 45^{\prime \prime} \mathrm{W}\end{array}$ & CORBIDI 16500 & MT531386 & MT524452 & MT522849 & - & MT512512 \\
\hline $\begin{array}{l}\text { Cercosaura } \\
\text { manicata } \\
\text { boliviana }\end{array}$ & $\begin{array}{c}\text { Santo Domingo, } \\
\text { Limbani, Sandia, } \\
\text { Puno }\end{array}$ & $\begin{array}{c}13^{\circ} 50^{\prime} 1^{\prime \prime} \\
\mathrm{S} / 69^{\circ} 38^{\prime} 29^{\prime \prime} \mathrm{W}\end{array}$ & CORBIDI 18716 & MT531387 & MT524453 & MT522848 & MT512515 & MT512511 \\
\hline Cercosaura sp. $\left(^{*}\right)$ & $\begin{array}{l}\text { Lanturachi, } \\
\text { Huancabamba, } \\
\text { Oxapampa }\end{array}$ & $\begin{array}{c}10^{\circ} 23^{\prime} 01^{\prime \prime} \\
\mathrm{S} / 75^{\circ} 34^{\prime} 49^{\prime \prime} \mathrm{W}\end{array}$ & MUBI 14515 & MT531388 & MT524456 & MT522847 & MT512514 & MT512510 \\
\hline
\end{tabular}

\subsection{DNA Extraction, Amplification, and Sequencing}

We obtained DNA sequences from five voucher specimens (Table 1). We extracted DNA from muscle tissues preserved in ethanol 96\% using a commercial kit (Catalog \#B47282, IBI Scientific). We obtained fragments of the nuclear oocyte maturation factor gene (c-mos), and the four mitochondrial genes: small subunit rRNA (12S), large subunit rRNA (16S), NADH dehydrogenase subunit 4 (ND4), and protein-coding cytochrome $\mathrm{b}(\mathrm{Cytb})$. We used standard primer and protocols for the polymerase chain reaction (PCR) (Table 2). We purified PCR products with Exosap-IT (Affymetrix, Santa Clara, CA, USA), and shipped purified products to MCLAB (San Francisco, CA, USA) for sequencing in both directions. We deposited new sequences in GenBank (Table 1). Additionally, we obtained 476 sequences of GenBank (https://www.ncbi.nlm.nih.gov/genbank/) of 124 terminals: $12 \mathrm{~S}$ (124 sequences), $16 \mathrm{~S}$ (123 sequences), ND4 (101 sequences), Cytb (19 sequences), and c-mos (109 sequences) (Table S1). We choose outgroups according to Moravec et al. [6].

Table 2. List of primers used in this study.

\begin{tabular}{|c|c|c|c|c|}
\hline Gene & Primer & Primers Sequence $\left(5^{\prime}-3^{\prime}\right)$ & PCR Cycle & Reference \\
\hline $12 \mathrm{~S}$ & $\begin{array}{l}12 \mathrm{~S} 1 \mathrm{~L} \\
12 \mathrm{~S} 2 \mathrm{H}\end{array}$ & $\begin{array}{l}\text { CAAACTGGGATTAGATACCCCACTAT } \\
\text { AGGGTGACGGGCGGTGTGT }\end{array}$ & $\begin{array}{c}94^{\circ} \mathrm{C} / 3 \mathrm{~min} ; 33 \times\left(95^{\circ} \mathrm{C} / 30 \mathrm{~s},\right. \\
\left.57^{\circ} \mathrm{C} / 30 \mathrm{~s}, 72{ }^{\circ} \mathrm{C} / 90 \mathrm{~s}\right) \\
72{ }^{\circ} \mathrm{C} / 10 \mathrm{~min}\end{array}$ & [31] \\
\hline $16 \mathrm{~S}$ & $\begin{array}{l}16 \mathrm{sF} .0 \\
16 \mathrm{sR} .0\end{array}$ & $\begin{array}{l}\text { CTGTTTACCAAAAACATMRCCTYTAGC } \\
\text { TAGATAGAAACCGACCTGGATT }\end{array}$ & $\begin{array}{c}96^{\circ} \mathrm{C} / 3 \mathrm{~min} ; 40 \times\left(95^{\circ} \mathrm{C} / 30 \mathrm{~s},\right. \\
\left.51^{\circ} \mathrm{C} / 60 \mathrm{~s}, 72{ }^{\circ} \mathrm{C} / 60 \mathrm{~s}\right) \\
72{ }^{\circ} \mathrm{C} / 10 \mathrm{~min}\end{array}$ & {$[31,32]$} \\
\hline ND4 & $\begin{array}{l}\text { ND412931L } \\
\text { ND413824H }\end{array}$ & $\begin{array}{l}\text { CTACCAAAAGCTCATGTAGAAGC } \\
\text { CATTACTTTTACTTGGATTTGCACCA }\end{array}$ & $\begin{array}{c}96^{\circ} \mathrm{C} / 3 \mathrm{~min} ; 40 \times\left(95^{\circ} \mathrm{C} / 30 \mathrm{~s},\right. \\
\left.52^{\circ} \mathrm{C} / 60 \mathrm{~s}, 72^{\circ} \mathrm{C} / 60 \mathrm{~s}\right) \\
72{ }^{\circ} \mathrm{C} / 10 \mathrm{~min}\end{array}$ & {$[33,34]$} \\
\hline Cytb & $\begin{array}{l}\text { L14841 } \\
\text { H15149 }\end{array}$ & $\begin{array}{l}\text { AAAAAGCTTCCATCCAACATCTCAGCATGATGAAA } \\
\text { AAACTGCAGCCCTCAGAATGATATTTGTCCTCA }\end{array}$ & $\begin{array}{c}94{ }^{\circ} \mathrm{C} / 5 \mathrm{~min} ; 30 \times\left(94{ }^{\circ} \mathrm{C} / 60 \mathrm{~s},\right. \\
\left.50^{\circ} \mathrm{C} / 60 \mathrm{~s}, 72{ }^{\circ} \mathrm{C} / 60 \mathrm{~s}\right) \\
72{ }^{\circ} \mathrm{C} / 10 \mathrm{~min}\end{array}$ & [31] \\
\hline c-mos & $\begin{array}{l}\text { G73 } \\
\text { G74 }\end{array}$ & $\begin{array}{l}\text { GCGGTAAAGCAGGTGAAGAAA } \\
\text { TGAGCATCCAAAGTCTCCAATC }\end{array}$ & $\begin{array}{c}96^{\circ} \mathrm{C} / 3 \mathrm{~min} ; 35 \times\left(95^{\circ} \mathrm{C} / 25 \mathrm{~s},\right. \\
\left.52^{\circ} \mathrm{C} / 60 \mathrm{~s}, 72{ }^{\circ} \mathrm{C} / 120 \mathrm{~s}\right) \\
72{ }^{\circ} \mathrm{C} / 10 \mathrm{~min}\end{array}$ & [35] \\
\hline
\end{tabular}

\subsection{Phylogenetic Reconstruction and Genetic Distances}

We aligned the sequences of each fragment independently in MUSCLE [36], implemented in MEGA-X [37]. We concatenated sequences of the five fragments using Mesquite V3.61 [38].

Three phylogenetic analyses were conducted by maximum likelihood (ML) for mitochondrial genes (12S, 16S, Cytb, ND4), a nuclear gene (c-mos), and combined data (mitochondrial + nuclear). We inferred the optimal partition scheme using PartitionFinder 2.1.1 under the Bayesian information criterion (BIC) [39]. The best scheme were nine partitions (12S, 16S, c-mos-pos1 and cmos-pos2, c-mos-pos3, Cytb-pos1, Cytb-pos2, Cytb-pos3 and ND4-pos3, ND4-pos1, and ND4-pos2), and the evolution models were GTR+I+G for 12S, 16S, and ND4-pos1, TIM+G for c-mos-pos1 and c-mos-pos2, 
K81UF+G for c-mos-pos3, SYM+I+G for Cytb-pos1, HKY for Cytb-pos2, TRN+G for Cytb-pos3 and ND4-pos3, and TVM+I+G for ND4-pos2. We inferred a phylogenetic tree using IQTREE 2 [40] and branch supports was estimated from 1000 pseudoreplicates using the ultrafast Bootstrap approach [41]. We uses Alopoglossus viridiceps, Bachia flavescens, Ecpleopus gaudichaudii, Gymnophthalmus leucomystax, Rhachisaurus brachylepis as outgroup taxa [6].

We estimated genetic distances between species (uncorrected p-distances) for 16S, which is the gene most commonly sequenced gene in gymnophthalmid lizards [6], and separately for 12S, ND4, and c-mos genes using Molecular Evolutionary Genetics Analysis (MEGA-X) [36] (Tables 3 and 4). Because the Cytb gene is poorly sampled in gymnophthalmid lizards, and available for only three species of Cercosaura, we omitted p-distances for this gene. 
Table 3. Uncorrected p-distances for $12 \mathrm{~S}$ (top) and $16 \mathrm{~S}$ (bottom) genes between Cercosaura anomala, Cercosaura sp., and "C. manicata boliviana" and other cercosaurine species.

\begin{tabular}{|c|c|c|c|c|c|c|c|c|c|c|c|c|c|c|c|}
\hline & 1 & 2 & 3 & 4 & 5 & 6 & 7 & 8 & 9 & 10 & 11 & 12 & 13 & 14 & 15 \\
\hline 1. Cercosaura anomala MUBI 13626 & & 0.073 & 0.095 & 0.06 & 0.121 & 0.065 & 0.069 & 0.086 & 0.078 & 0.073 & 0.06 & 0.082 & 0.073 & 0.069 & 0.065 \\
\hline 2. Cercosaura argulus QCAZ 4888 & 0.065 & & 0.073 & 0.073 & 0.103 & 0.095 & 0.091 & 0.069 & 0.043 & 0.039 & 0.082 & 0.039 & 0.034 & 0.108 & 0.082 \\
\hline 3. Cercosaura bassleri CORBIDI 11218 & 0.078 & 0.06 & & 0.099 & 0.112 & 0.112 & 0.108 & 0.06 & 0.082 & 0.06 & 0.103 & 0.078 & 0.073 & 0.121 & 0.082 \\
\hline 4. Cercosaura doanae CORBIDI 650 & 0.067 & 0.073 & 0.071 & & 0.116 & 0.052 & 0.052 & 0.095 & 0.086 & 0.091 & 0.069 & 0.099 & 0.091 & 0.052 & 0.073 \\
\hline 5. Cercosaura eigenmanni MRT 976979 & 0.071 & 0.058 & 0.048 & 0.08 & & 0.121 & 0.116 & 0.099 & 0.108 & 0.108 & 0.121 & 0.108 & 0.116 & 0.125 & 0.121 \\
\hline 6. Cercosaura manicata CORBIDI 8837 & 0.056 & 0.065 & 0.082 & 0.067 & 0.089 & & 0.022 & 0.116 & 0.091 & 0.095 & 0.073 & 0.095 & 0.086 & 0.047 & 0.078 \\
\hline 7. Cercosaura manicata QCAZ 5793 & 0.037 & 0.048 & 0.069 & 0.054 & 0.071 & 0.03 & & 0.112 & 0.086 & 0.082 & 0.06 & 0.082 & 0.073 & 0.034 & 0.073 \\
\hline 8. Cercosaura ocellata MRT 977406 & 0.095 & 0.067 & 0.065 & 0.08 & 0.054 & 0.095 & 0.082 & & 0.078 & 0.073 & 0.112 & 0.065 & 0.078 & 0.095 & 0.065 \\
\hline 9. Cercosaura oshaughnessyi QCAZ 4623 & 0.076 & 0.054 & 0.052 & 0.078 & 0.054 & 0.078 & 0.06 & 0.069 & & 0.047 & 0.078 & 0.047 & 0.052 & 0.095 & 0.056 \\
\hline 10. Cercosaura parkeri LG 1560 & 0.082 & 0.058 & 0.063 & 0.086 & 0.06 & 0.073 & 0.063 & 0.067 & 0.058 & & 0.069 & 0.017 & 0.013 & 0.091 & 0.069 \\
\hline 11. Cercosaura quadrilineata LG 936 & 0.086 & 0.069 & 0.084 & 0.089 & 0.069 & 0.084 & 0.069 & 0.071 & 0.08 & 0.076 & & 0.082 & 0.073 & 0.078 & 0.065 \\
\hline 12. Cercosaura schreibersii albostrigatus LG 1168 & 0.063 & 0.054 & 0.056 & 0.078 & 0.048 & 0.076 & 0.056 & 0.071 & 0.052 & 0.041 & 0.069 & & 0.022 & 0.091 & 0.078 \\
\hline 13. Cercosaura schreibersii schreibersii LG 927 & 0.069 & 0.06 & 0.056 & 0.08 & 0.054 & 0.078 & 0.058 & 0.076 & 0.054 & 0.043 & 0.08 & 0.026 & & 0.082 & 0.073 \\
\hline 14. Cercosaura sp. MUBI 14515 & 0.06 & 0.069 & 0.067 & 0.032 & 0.073 & 0.058 & 0.041 & 0.073 & 0.067 & 0.071 & 0.065 & 0.065 & 0.067 & & 0.065 \\
\hline 15. Cercosaura manicata boliviana CORBIDI 18716 & 0.056 & 0.063 & 0.071 & 0.069 & 0.067 & 0.065 & 0.045 & 0.078 & 0.06 & 0.071 & 0.082 & 0.058 & 0.065 & 0.067 & \\
\hline
\end{tabular}

Table 4. Uncorrected p-distances for ND4 (top) and c-mos (bottom) genes between Cercosaura anomala, Cercosaura sp., and "C. manicata boliviana" and other cercosaurine species.

\begin{tabular}{|c|c|c|c|c|c|c|c|c|c|c|c|c|c|c|c|}
\hline & 1 & 2 & 3 & 4 & 5 & 6 & 7 & 8 & 9 & 10 & 11 & 12 & 13 & 14 & 15 \\
\hline 1. Cercosaura anomala MUBI 13626 & & 0.196 & 0.188 & 0.187 & 0.187 & 0.195 & 0.185 & 0.198 & 0.187 & 0.176 & 0.18 & 0.18 & 0.179 & 0.176 & 0.176 \\
\hline 2. Cercosaura argulus QCAZ 4888 & 0.033 & & 0.167 & 0.174 & 0.169 & 0.177 & 0.193 & 0.164 & 0.122 & 0.153 & 0.179 & 0.147 & 0.159 & 0.201 & 0.214 \\
\hline 3. Cercosaura bassleri CORBIDI 11218 & 0.033 & 0.023 & & 0.187 & 0.167 & 0.177 & 0.171 & 0.179 & 0.184 & 0.176 & 0.187 & 0.185 & 0.174 & 0.196 & 0.192 \\
\hline 4. Cercosaura doanae CORBIDI 650 & 0.016 & 0.039 & 0.036 & & 0.164 & 0.129 & 0.127 & 0.185 & 0.179 & 0.161 & 0.176 & 0.156 & 0.161 & 0.093 & 0.166 \\
\hline 5. Cercosaura eigenmanni MRT 976979 & 0.029 & 0.02 & 0.01 & 0.033 & & 0.18 & 0.184 & 0.192 & 0.167 & 0.166 & 0.192 & 0.151 & 0.166 & 0.182 & 0.221 \\
\hline 6. Cercosaura manicata CORBIDI 8837 & 0.02 & 0.042 & 0.036 & 0.01 & 0.036 & & 0.09 & 0.19 & 0.192 & 0.184 & 0.195 & 0.164 & 0.176 & 0.135 & 0.187 \\
\hline 7. Cercosaura manicata QCAZ 5793 & 0.02 & 0.042 & 0.036 & 0.01 & 0.036 & 0 & & 0.184 & 0.182 & 0.176 & 0.169 & 0.158 & 0.182 & 0.127 & 0.179 \\
\hline 8. Cercosaura ocellata MRT 977406 & 0.039 & 0.029 & 0.013 & 0.042 & 0.016 & 0.036 & 0.036 & & 0.177 & 0.161 & 0.193 & 0.184 & 0.167 & 0.188 & 0.2 \\
\hline 9. Cercosaura oshaughnessyi QCAZ 4623 & 0.042 & 0.039 & 0.036 & 0.039 & 0.033 & 0.036 & 0.036 & 0.036 & & 0.135 & 0.174 & 0.153 & 0.159 & 0.196 & 0.203 \\
\hline 11. Cercosaura quadrilineata LG 936 & 0.046 & 0.049 & 0.046 & 0.042 & 0.042 & 0.046 & 0.046 & 0.052 & 0.049 & 0.039 & & 0.203 & 0.198 & 0.188 & 0.176 \\
\hline 12. Cercosaura schreibersii albostrigatus LG 1168 & 0.033 & 0.016 & 0.013 & 0.029 & 0.01 & 0.033 & 0.033 & 0.02 & 0.029 & 0 & 0.039 & & 0.118 & 0.169 & 0.203 \\
\hline 13. Cercosaura schreibersii schreibersii LG 927 & 0.033 & 0.016 & 0.013 & 0.029 & 0.01 & 0.033 & 0.033 & 0.02 & 0.029 & 0 & 0.039 & 0 & & 0.182 & 0.166 \\
\hline 14. Cercosaura sp. MUBI 14515 & 0.01 & 0.039 & 0.029 & 0.007 & 0.026 & 0.01 & 0.01 & 0.036 & 0.039 & 0.029 & 0.042 & 0.029 & 0.029 & & 0.179 \\
\hline 15. Cercosaura manicata boliviana CORBIDI 18716 & 0.023 & 0.052 & 0.042 & 0.026 & 0.039 & 0.029 & 0.029 & 0.049 & 0.052 & 0.042 & 0.055 & 0.042 & 0.042 & 0.02 & \\
\hline
\end{tabular}




\subsection{Designation of Neotype and Species Descriptions}

In the original description of Pholidobolus anomalus, Müller [21] was not very precise about the type locality, and mentioned Cusco as the collecting locality. However, the most probable place where the holotype was collected is the Historical Sanctuary of Machupicchu (HSM), in the Cordillera de Vilcabamba. After its discovery by Hiram Bingham in 1911, the HSM became very popular with naturalists. The resulting scientific collections were deposited in different natural history museums [42,43].

We designed a neotype of Pholidobolus anomalus because the holotype was lost. This designation is covered by Article 75.3 of the International Code of Zoological Nomenclature (ICZN) [44]. We used the neotype to redescribe the species, and support the generic allocation. We followed Uzzell [45], Kizirian [46], and Doan and Cusi [24] for character definitions and measurements, and Chávez et al. [7] for description format. One of us (LM) observed morphological characters of species and took all measurements using a caliper with a precision of $0.1 \mathrm{~mm}$. We referred to the literature for patterns of scalation and coloration of the following taxa: Cercosaura anordosquama, C. ocellata, C. bassleri and C. olivacea [13]; Cercosaura argulus, C. eigenmanni, and C. oshaughnessyi [47]; C. hypnoides [17]; C. quadrilineata, C. schreibersii, and C. phelpsorum [18]; C. doanae [16]; C. manicata [30]; C. nigroventris [48]; C. parkeri [49]; and C. steyeri [50]. We also examined specimens of Cercosaura deposited in the CORBIDI, MUBI, and MUSA collections (Appendix A).

This research was approved by the Institutional Animal Care and Use Committee of Southern Illinois University Carbondale (protocol \#16-006). The Dirección General Forestal y de Fauna Silvestre, Ministerio de Agricultura y Riego, and Servicio Nacional Forestal y de Fauna Silvestre issued the permit authorizing this research (permits \#210-2013-MINAGRI- DGFFS/DGEFFS, 0642013-AG-DGFFS-DGEFFS, 359-2013-MINAGRI-DGFFS- DGEFFS, 292-2014-MINAGRI-DGFFS-DGEFFS, 024-2017-SERFOR/DGGSPFFS, and 369-2019-MINAGRI-SERFOR-DGGSPFFS).

The electronic version of this article in portable document format will represent a published work according to the International Commission on Zoological Nomenclature, and hence the new names contained in the electronic version are effectively published under that Code from the electronic edition alone. This published work and the nomenclatural acts it contains have been registered in ZooBank, the online registration system for the ICZN. The Life Sciences Identifier (LSID) for this publication is: urn:lsid:zoobank.org:pub:FF0EC17F-965E-410D-AF0A-356B19BD4431.

\section{Results}

\subsection{Phylogenetic Relationships}

Our phylogenetic ML (Figure 2) tree inferred using fragments of four mitochondrial and one nuclear gene is congruent with other studies $[6,11,12,51,52]$, except that it recovered the monophyly of Proctoporus and that the recently described genus Wilsonosaura is nested within the Proctoporus lineage (Bootstrap: 76). However, trees using only mitochondrial (Figure S1) and nuclear (Figure S2) markers are not congruent. Our ML analyses using the full dataset recovered the polyphyly of genera Cercosaura and Pholidobolus. Pholidobolus anomalus and Cercosaura sp. (MUBI 14515) were nested within Cercosaura, whereas Cercosaura manicata boliviana was nested with Potamites and Selvasaura. Likewise, our mixed ML analyses recovered the monophyly of the genera: Anadia (98), Andinosaura (99), Cercosaura (including C. anomala, 85), Dendrosauridion (99), Echinosaura (100), Gelanesaurus (100), Neusticurus (100), Macropholidus (100), Pholidobolus (99), Placosoma (100), Potamites (100), Proctoporus (76), Selvasaura (100), and Riama (100). Euspondylus and Rheosaurus (both with a single known species) were recovered as independent lineages. Our phylogeny inferred using the full dataset is congruent with other studies, and may better reflect the evolutionary history of the lineages [53]. 


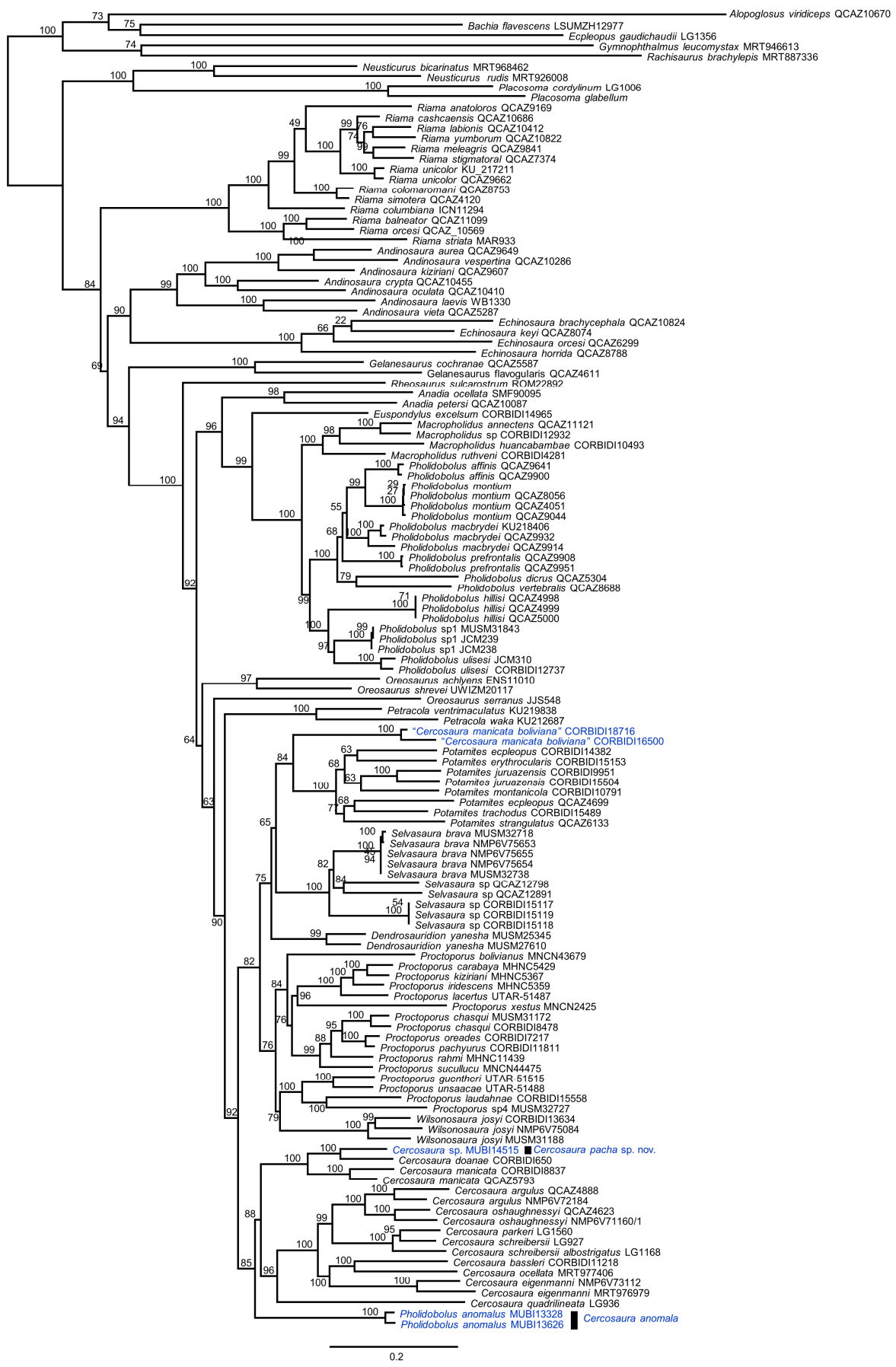

Figure 2. Maximum likelihood tree (log likelihood $=-44,674.306$, ultrafast boostrap $=1000$ ) showing the phylogenetic relationships of Cercosaura, Pholidobolus anomalus, and other gymnophthalmid lizards. The numbers next to the nodes are bootstrap values. The analysis was constructed from a concatenated dataset of $2167 \mathrm{bp}$ of four mitochondrial genes (12S, 16S, Cytb, ND4) and a nuclear gene (c-mos). In blue are the samples obtained in this study.

The uncorrected p-distance of the $16 \mathrm{~S}$ gene between Pholidobolus anomalus and other taxa were: Cercosaura manicata (3.7-5.6\%), Cercosaura sp. (6\%), and C. ocellata (9.5\%). Cercosaura sp. has a distance of $3.2 \%$ with respect to its sister species (Cercosaura doanae). Genetic distances among Cercosaura manicata boliviana and any other species of Cercosaura exceeded $4.5 \%$ (Table 3). The uncorrected p-distances between Cercosaura sp. and C. doanae in $12 \mathrm{~S}(5.2 \%)$, ND4 $(9.3 \%)$, c-mos $(0.7 \%)$ genes were always greater than the intraspecific distance of $C$. manicata in $12 \mathrm{~S}(2.2 \%), \mathrm{ND} 4(9.0 \%)$, and c-mos $(0.0 \%)$. These uncorrected 
p-distance between Cercosaura sp. and $C$. doanae are outside the intraspecific range, and within the interspecific range for species of gymnophthalmid lizards [11].

Based on our molecular analyses (Figure 2, Tables 3 and 4), we conclude (1) that P. anomalus needs to be redescribed and allocated to the genus Cercosaura, including designating a neotype; (2) Cercosaura sp. (MUBI 14515) is a new species; and (3) Cercosaura manicata boliviana is a valid species, the sister lineage of the semiaquatic lizards of the genus Potamites [20], but considered here as incertae sedis.

\subsection{Taxonomy}

Cercosaura anomala new. comb. (Müller, 1923)

Pholidobolus anomalus Müller, 1923

Neotype: MUBI 5277 (Figure 3), an adult male from Puente Ruinas, Santuario Histórico de Machupicchu, District of Machupicchu, Province of Urubamba, Department of Cusco, Peru $\left(13^{\circ} 09^{\prime} 42^{\prime \prime}\right.$ S, 72 $32^{\prime} 07^{\prime \prime}$ W, at $2060 \mathrm{~m}$ ), collected by J.C. Chaparro on 20 April 1998.
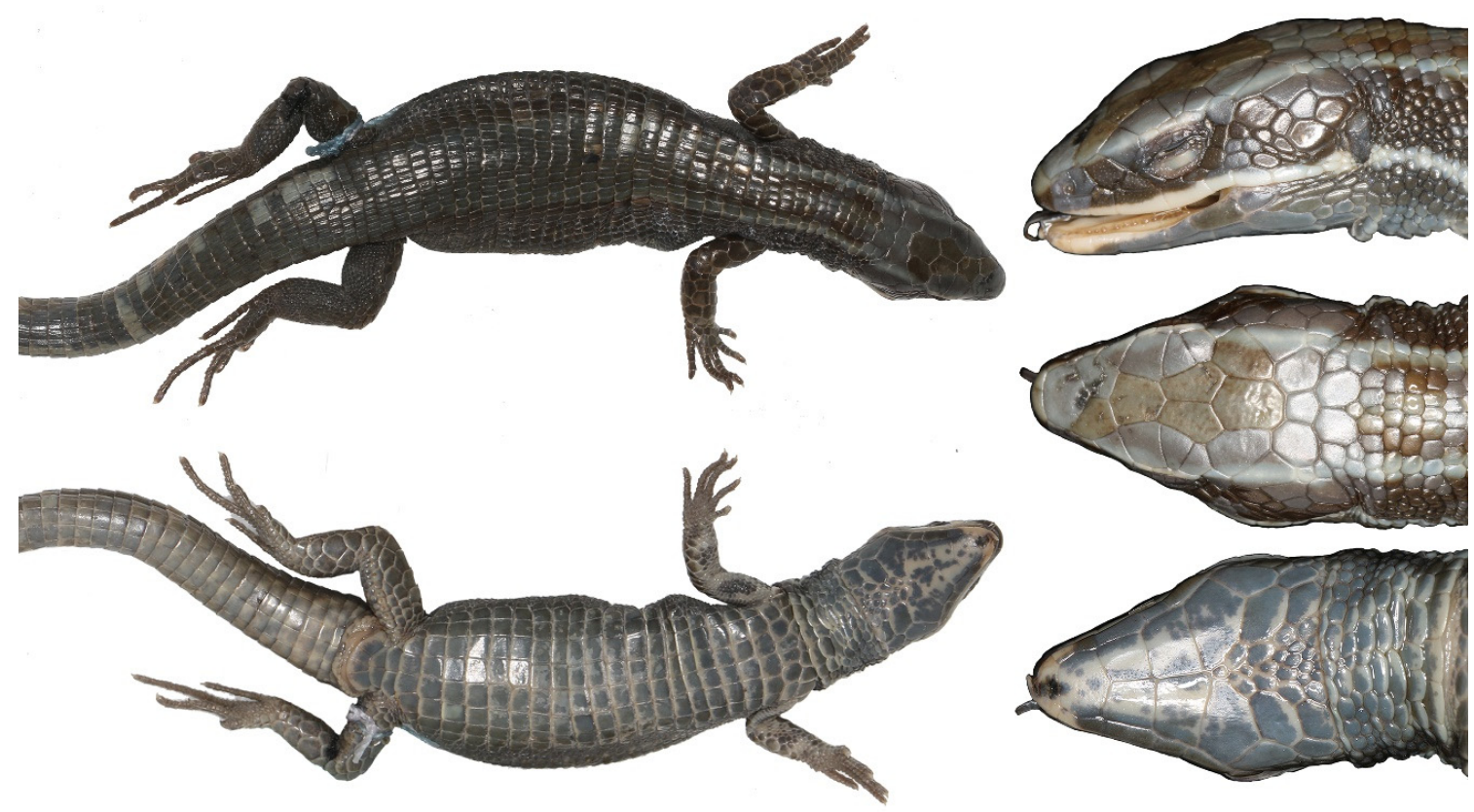

Figure 3. Neotype of Cercosaura anomala, male MUBI 5277 (snout vent length (SVL) $=60.7 \mathrm{~mm}$ ).

Referred specimens: An adult male (MUBI 641), an adult female (MUBI 640), and a subadult female (MUBI 819) from the same locality as the neotype; two adult females (MUBI 13328, 13626), and a subadult female (MUBI 13529) from Vilcabamba (Figure 4A,B); a subadult male (MUSA 4537) from Maranura; and an adult male (MUBI 16169) from Quellouno (Figure 4C,D). All sites are located in Department of Cusco. 


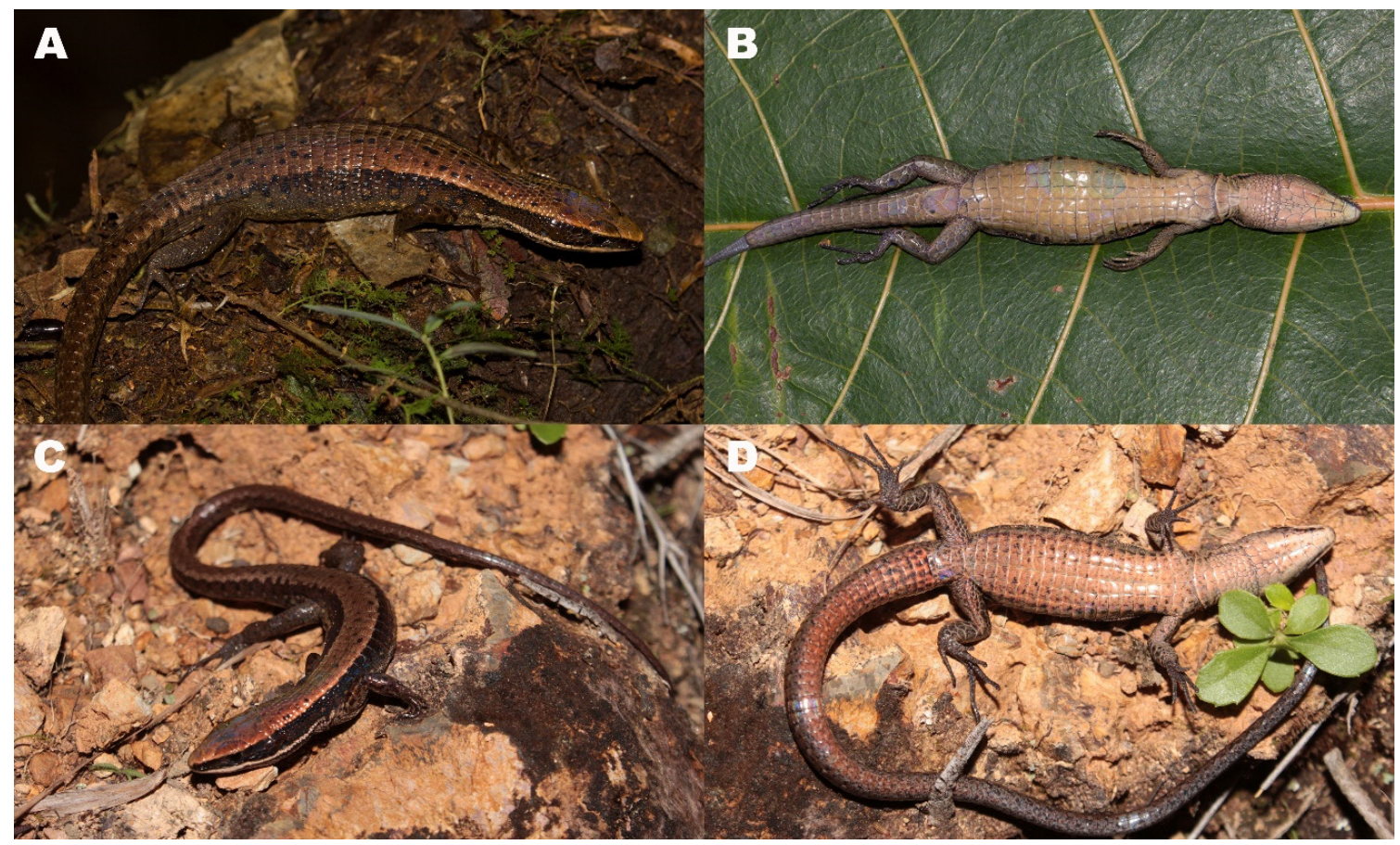

Figure 4. Live specimens of Cercosaura anomala. (A, B) Adult females (Urusayhua, Vilcabamba, (A) MUBI 13626, SVL = 68.2 mm, (B) MUBI 13328, SVL = $72.1 \mathrm{~mm}$ ); (C, D) Adult male (Quellouno, La Convención, MUBI 16169, SVL = 56.2 mm). Photo: (A, B) Luis Mamani, (C, D) Juan C. Chavez-Arribasplata.

Etymology: The specific epithet "anomalus" is a nominative adjective in ancient Latin meaning irregular (anomalus), which implicitly refers to the presence and irregular shape of the prefrontal scales; then anomala (feminine nominative) must follow the genus Cercosaura (feminine).

Diagnosis: (1) Body robust, maximum snout vent length (SVL) of females, $72.1 \mathrm{~mm}$; males, $61.7 \mathrm{~mm}$; (2) head flat, elongated, 1.5 times longer than wide; (3) ear opening distinct, slightly recessed; (4) nasals separated by frontonasal; (5) frontonasal undivided; (6) prefrontal, frontal, frontoparietals, parietals and interparietals present, prefrontal scales in contact, occasionally separate; (7) parietal longer than wide; (8) three supraoculars, three postoculars, three infraoculars; (9) three superciliars, complete series; (10) nasal suture present; (11) loreal present; (12) 7-8 supralabials, four supralabials anterior to the posteroventral angle of the subocular, occasionally five, 6-8 infralabials; (13) 5-6 genials in contact; (14) collar fold present; (15) 33-36 transverse rows of dorsal scales, hexagonal, slightly keeled, imbricate; (16) 19-22 transverse rows of ventral scales, quadrangular, smooth, juxtaposed; (17) 35-43 scales around midbody; (18) lateral reduced scales at midbody in 3-4 lines; (19) limbs pentadactyl, all digits clawed; (20) 12-14 subdigital lamellae under finger IV, 17-19 under toe IV; (21) 8-10 femoral pores in males, 4-6 in females; (22) 2 preanal scales, 3-4 postanal scales; (23) tail up to 1.9-2.6 times longer than body; (24) caudals subimbricate, keeled dorsally, smooth ventrally; (25) lower palpebral disc transparent and undivided; (26) in life the dorsum is light-brown with some black spots, flanks dark brown with diffuse ocelli; lips with a cream line that extends to the front of arm insertion; ventral surface cream-reddish with some small scattered black spots, gular region of head cream-reddish with small black spots (Figure 4).

Cercosaura anomala is very similar to C. hypnoides, C. manicata, and C. doanae; all of which present a clear labial bar on both sides of the head and similar dorsal and lateral colorations. However, C. anomala differs from all other species of Cercosaura by the presence of smooth dorsal scales on the neck. In addition, $C$. anomala can be differentiated from $C$. argulus by the frontonasal scale being undivided (divided in C. argulus), 5-6 genial scales in contact (four genials in C. argulus); from C. anodorsquama, C. bassleri, C. olivacea, and C. ocellata because the keels of dorsal scales do not form lines arranged on the back (the keels of dorsal scales form continuous lines arranged on the back); from C. hypnoides by 
the presence of eight longitudinal ventral scales (six in C. hypnoides), absence of dorsolateral stripes (presence of continuous cream dorsolateral stripes in C. hypnoides); from $C$. doanae by the presence of dorsal scales with low keels (strongly keeled in C. doanae), maximum SVL of $72.1 \mathrm{~mm}$ in females ( $55.6 \mathrm{~mm}$ in C. doanae); from C. eigenmanni by the presence of $35-43$ scales around the body (26-32 scales in C. eigenmanni), maximum SVL of $72.1 \mathrm{~mm}$ in females ( $47.0 \mathrm{~mm}$ in C. eigenmanni); from C. manicata by the presence of dorsal scales with low keels (strongly keeled in C. manicata), dorsal scales with the anterior and posterior edges almost blunt (anterior and posterior edges pointed in C. manicata); from C. nigroventris by the presence of 5-6 genials in contact (four genials in contact in C. nigroventris), maximum SVL of $61.7 \mathrm{~mm}$ in males (44.1 $\mathrm{mm}$ in C. nigroventris); from C. oshaughnessyi by the presence of the frontonasal scale not divided (divided in two in C. oshaughnessyi), maximum SVL of $72.1 \mathrm{~mm}$ in females (51 $\mathrm{mm}$ in C. oshaughnessyi); from C. parkeri by the presence of 35-43 scales around the body (24-30 in C. parkeri), 8-10 femoral pores per leg in males (3-5 per leg in C. parkeri); from C. phelpsorum by the presence of a white line on the upper lip (without a white line in C. phelpsorum), maximum SVL of $72.1 \mathrm{~mm}$ in females ( $55 \mathrm{~mm}$ in C. phelpsorum); from C. quadrilineata by the presence of $35-43$ scales around the body (26 in C. quadrilineata), presence of 8-9 longitudinal ventral scales (four in C. quadrilineata); from C. schreibersii by the presence of three postoculars (two in C. schreibersii), 8-10 femoral pores per leg in males (3-6 in C. schreibersii); from C. steyeri by the presence of 8-9 longitudinal ventral scales (four in C. steyeri), dorsal scales not mucronate (dorsal scales mucronate in C. steyeri).

Description of the neotype (MUBI 5277): Adult male, SVL $=60.7 \mathrm{~mm}$, tail length $=126.4 \mathrm{~mm}$; head scales smooth, without striations, or rugosities; rostral scale wider $(2.6 \mathrm{~mm})$ than tall $(1.5 \mathrm{~mm})$, meeting supralabials on either side at above the height of supralabials, and becoming higher medially, in contact with frontonasal, nasal, and first supralabials; frontonasal pentagonal, wider than longer, widest in the mid, in contact with rostral, nasal, and prefrontals; prefrontals paired, pentagonal in contact with frontonasal, loreal, first superciliar, first supraocular, and frontal; frontal longer than wide, hexagonal, not in contact with superciliars, but in contact with first supraocular, and frontoparietals; frontoparietals polygonal, in contact with the frontal, all supraoculars, parietals, and interparietal; three supraoculars, all in contact with superciliaries, frontal, frontoparietals, parietal, and postocular; interparietal longer than wide, heptagonal, in contact with frontoparietals anteriorly, with parietal laterally, and with postparietals posteriorly; parietals polygonal, anteriorly in contact with frontoparietals, third supraocular, and postocular, laterally in contact with interparietals and supratemporals, and posteriorly with postparietals; three postparietals, smaller than parietals, the mid postparietal is smaller than lateral postparietals. Nasal divided, longer than high, in contact with first, and second supralabials; loreal present, in contact with second and third supralabials, in contact with nasal, first superciliar, and frenocular; four superciliars, first expanded onto surface of head; frenocular triangular in contact with third supralabials, first subocular, and loreal scales; palpebral disc made up of a single transparent scale; three suboculars; three postoculars; temporals smooth, glossy, and polygonal; four anterior supralabials to the posteroventral angle of the third subocular. Mental wider than long, in contact with first infralabial, and postmental; postmental single, polygonal, in contact with first and second infralabial, and first pairs of genials; three pairs of genials, five in contact, anterior pair in contact with second and third infralabials, middle pair in contact with third, fourth and fifth infralabials, posterior pair of genials in contact with fifth infralabial, and pregulars; two enlarged pregulars on left and right side, and 22 small pregulars irregularly distributed among enlarged pregulars; eight rows of gular scales including the collar, and the middle scales enlarged; collar fold distinct; lateral neck scales round, and smooth; dorsal neck scales smooth. Dorsal hexagonal, longer tan wide, juxtaposed, slightly keeled, in 36 transverse dorsal scale rows; 27 longitudinal dorsal scale rows at midbody; continuous lateral scale series, smaller than dorsals; reduced scales at limb insertion regions present; 22 transverse ventral scale rows; eight longitudinal ventral scale rows at midbody; a pair of anterior preanal plate scales; four posterior preanal plate scales; scales on tail rectangular, juxtaposed, and smooth. Limbs pentadactyl; digits clawed; dorsal brachial scales polygonal, imbricate, and smooth; ventral brachial scales small, rounded, and smooth; antebrachial scales polygonal, subequal in size, 
smooth, and imbricate; ventral antebrachial small, subimbricate, and rounded; dorsal manus scales polygonal, smooth, and subimbricate; palmar scales small, rounded, and domelike; dorsal scale on fingers smooth, quadrangular, imbricate, three on finger I, six on II, eight on III, nine on IV, and five on V; scales on anterodorsal surface of thigh large, polygonal, smooth, and subimbricate; scales on posterior surface of thigh small, rounded, juxtaposed, and keeled; scales on ventral surface of thigh large, roundish, flat, and smooth; nine femoral pores; preanal pores absent; scales on anterior surface of crus polygonal, keeled, and juxtaposed, decreasing in size distally; scales on posterior surface of crus small, roundish, keeled, and subimbricate; scales on dorsal surface of foot polygonal, smooth, and imbricate; scales on ventral surface of foot small, rounded, juxtaposed, and domelike; scales on dorsal surface of toes quadrangular, smooth, overhanging supradigital lamellae, four on toe I, seven on II, 10 on III, 12 on IV, and eight on V; fore and hind limbs overlapping when adpressed against the body.

Coloration in preservative: The dorsal surface of the head, neck, and body is brown with two clear dorsolateral lines on both sides of head that start from the supraoculars and disappear at the middle of body; the lateral surface of the head, neck, and body is dark brown; on both sides of the head and neck there is a cream labial line that extends from the tip of the head to the anterior part of the insertion of brachium; the ventral surface of the head, neck and body is dark gray with irregular cream spots. The dorsal surface of the limbs is brown, and ventral surface of limbs is similar to the ventral surface of the body (Figure 3).

Coloration in life: According to notes and photographs taken by LM of live specimens, the dorsal surface of the head and neck is brown with small black spots; the lateral sides of the head and neck are blackish brown with a cream labial line that extends from the tip of the head to the anterior part of the insertion of brachium; the ventral surface of the head is cream with small brown spots scattered; pregular and gular regions are similar to the ventral surface of head. The dorsal surface of body is brown with scattered black spots; lateral surface of body is blackish brown with black and cream spots that resemble ocelli; the ventral surface of body is reddish cream with scattered black spots. The dorsal surface of the limbs is brown with small black spots, the ventral surface is reddish cream with small black spots. The dorsal surface of the tail is similar to the dorsum, and the ventral surface of the limbs is similar to the ventral surface of the body (Figure 4).

Variation: Morphometric characters and pholidosis are presented in Table 5; Cercosaura anomala apparently has sexual dimorphism in size, females (maximum SVL $=72.1 \mathrm{~mm}, \mathrm{n}=5$ ) are larger than males (maximum SVL $=61.7 \mathrm{~mm}, \mathrm{n}=4$ ). The condition of the prefrontal scales is variable, all specimens examined have joined prefrontal scales, and only one subadult female (MUBI 819) and the lost specimen (holotype) have small and separate prefrontal scales.

Distribution and natural history: Cercosaura anomala inhabits montane forests on the eastern slopes of Cordillera de los Andes, in Department of Cusco, between 1745-2218 m a.s.l. We have observed this lizard on litter and on rocks from 10:00 to 14:00 h on sunny days at five localities in the Cordillera de Vilcabamba: Urusayhua, Tucantinas, Historical Sanctuary of Machupicchu, Maranura, and Quellouno (Figures 1 and 5). Sympatric gymnophthalmid lizards include Proctoporus machupicchu, P. guentheri, P. unsaacae, and Proctoporus sp. [8]. 
Table 5. Morphometric measurements and pholidosis of Cercosaura anomala and C. pacha sp. nov.

\begin{tabular}{|c|c|c|c|c|c|c|c|c|}
\hline \multirow{4}{*}{ Measurements (mm) } & \multicolumn{6}{|c|}{ Cercosaura anomala (all adults) } & \multicolumn{2}{|c|}{ Cercosaura pacha sp. nov. } \\
\hline & MUBI & MUBI & MUBI & MUBI & MUBI & MUBI & MUBI & MUBI \\
\hline & 641 & 5277 & 16169 & 13626 & 640 & 13328 & 14515 & 14512 \\
\hline & Male & Male & Male & Female & Female & Female & Female & Subadult Female \\
\hline Snout-vent length & 61.7 & 60.69 & 56.2 & 68.22 & 70.08 & 72.05 & 49.7 & 32.4 \\
\hline Tail length & 72.6 & 126.44 & 146.2 & 130.3 & 107.3 & 40.87 & 98.1 & 41 \\
\hline Head length (chin to eardrum) & 13.3 & 13.22 & 13.1 & 14.31 & 14.18 & 14.75 & 10.8 & 7.8 \\
\hline Head width & 10 & 8.95 & 8 & 9.37 & 9.58 & 9.09 & 7.8 & 5.4 \\
\hline Postoculars & 3 & 3 & 3 & 3 & 3 & 3 & 3 & 3 \\
\hline Superciliars & $4 / 4$ & $4 / 4$ & $4 / 4$ & $4 / 4$ & $4 / 4$ & $4 / 4$ & $4 / 5$ & $3 / 3$ \\
\hline Palpebral disc & entire & entire & entire & entire & entire & entire & divided & $1 / 2$ \\
\hline Prefrontal scales & present & present & present & present & present & present & present & present \\
\hline Nasoloreal suture & present & present & present & present & present & present & present & present \\
\hline Supralabials & $7 / 8$ & $8 / 8$ & $7 / 8$ & $8 / 8$ & $7 / 7$ & $7 / 8$ & $8 / 8$ & $7 / 7$ \\
\hline $\begin{array}{l}\text { Supralabials anterior to the } \\
\text { posteroventral angle of the } \\
\text { subocular }\end{array}$ & $4 / 5$ & $4 / 4$ & $4 / 4$ & $4 / 4$ & $4 / 4$ & $4 / 4$ & $4 / 4$ & $4 / 4$ \\
\hline Suboculars & 3 & 3 & 3 & 3 & 3 & 3 & 3 & 3 \\
\hline Infralabials & $6 / 7$ & $7 / 7$ & $7 / 7$ & $7 / 7$ & $8 / 7$ & $7 / 7$ & $6 / 6$ & $6 / 6$ \\
\hline Femoral pores & 9/9 & 9/9 & $9 / 10$ & $5 / 6$ & $4 / 5$ & $4 / 4$ & $7 / 7$ & $6 / 6$ \\
\hline Loreal & present & present & present & present & present & present & present & present \\
\hline Supraoculars & 3 & 3 & 3 & 3 & 3 & 3 & 3 & 3 \\
\hline Genials in contact & 5 & 5 & 6 & 6 & 6 & 6 & 5 & 4 \\
\hline Gular rows & 9 & 9 & 8 & 9 & 9 & 9 & 8 & 7 \\
\hline Postparietals & 5 & 5 & 5 & 5 & 5 & 3 & 3 & 2 \\
\hline Scales around midbody & 38 & 35 & 39 & 39 & 40 & 40 & 38 & 37 \\
\hline Longitudinal dorsal count & 24 & 27 & 31 & 27 & 24 & 25 & 30 & 29 \\
\hline Longitudinal ventral count & 9 & 8 & 8 & 8 & 8 & 8 & 8 & 8 \\
\hline Transversal dorsal count & 34 & 36 & 34 & 35 & 33 & 33 & 35 & 32 \\
\hline Transversal ventral count & 22 & 21 & 19 & 19 & 21 & 19 & 20 & 19 \\
\hline Lamellae under finger IV & 14 & 13 & 14 & 13 & 14 & 13 & 13 & 12 \\
\hline Lamellae under toe IV & 18 & 18 & 19 & 19 & 19 & 18 & 18 & 18 \\
\hline Anal plate & 6 & 6 & 5 & 6 & 6 & 5 & 5 & 5 \\
\hline
\end{tabular}

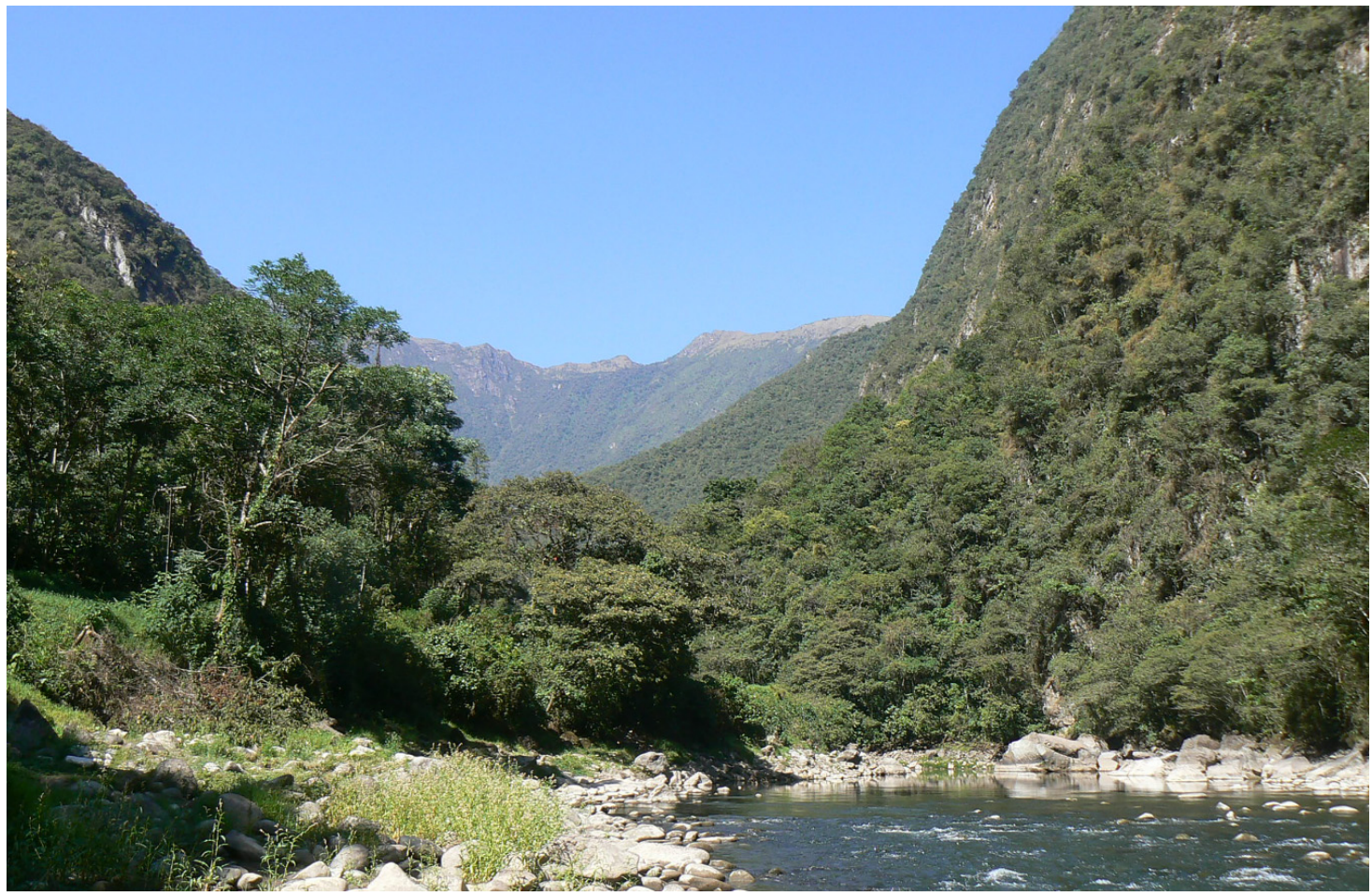

Figure 5. Habitat of Cercosaura anomala in the montane forest of the Historical Sanctuary of Machupicchu, Department of Cusco.

Cercosaura pacha sp. nov.

Zoobank LSID: urn:lsid:zoobank.org:act:6B3FCF87-82E4-4E2B-8C3B-99FD93E051CD 
Holotype: MUBI 14515 (Figure 6), an adult female from Lanturachi, Fundo los Cocos, District of Huancabamba, Province of Oxapampa, Department of Pasco, Peru $\left(10^{\circ} 23^{\prime} 02^{\prime \prime}\right.$ S, $75^{\circ} 34^{\prime} 49^{\prime \prime}$ W, at 1986 m), collected by J.C. Chaparro and C. Alarcón on 21 September 2014.

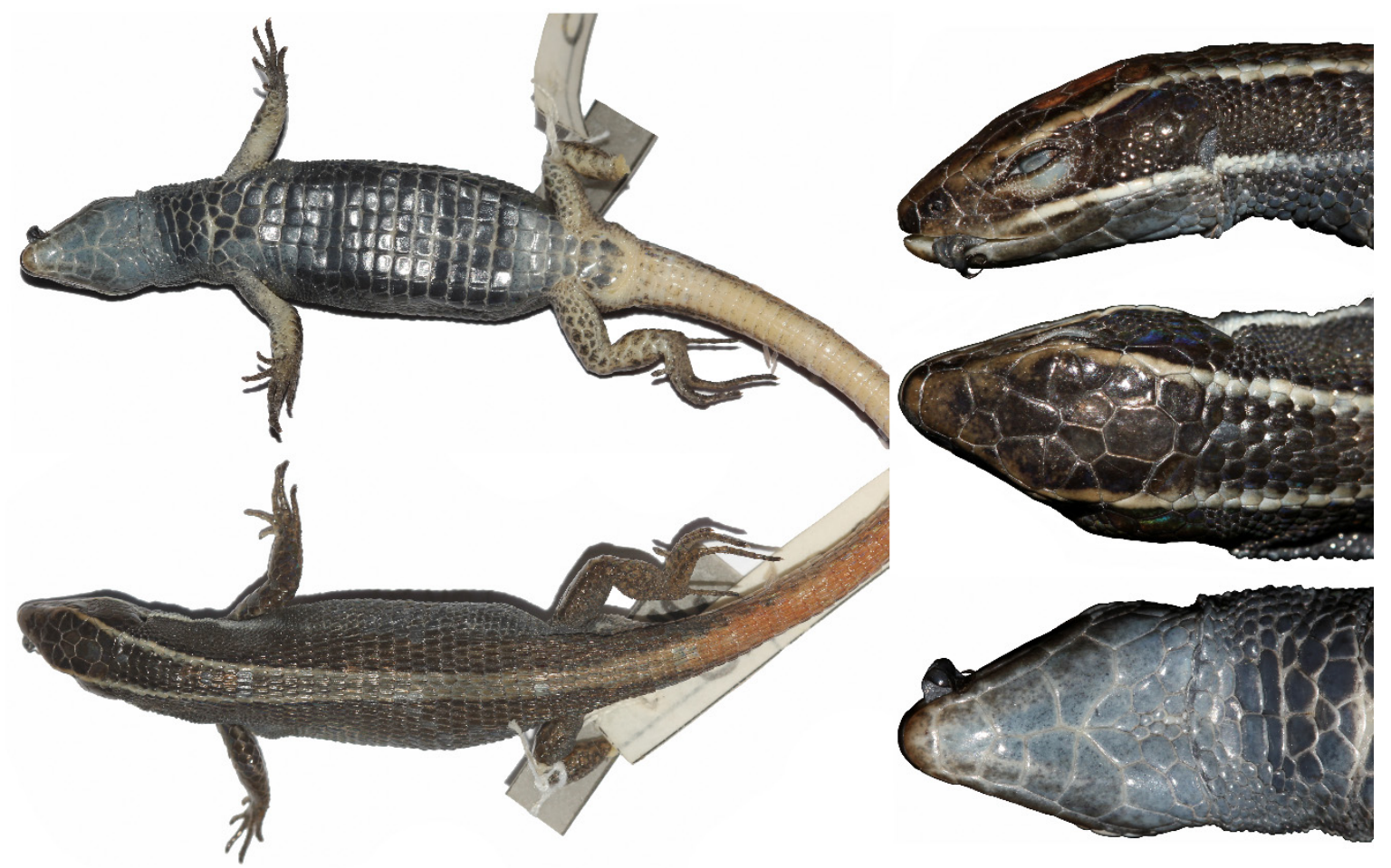

Figure 6. Holotype of Cercosaura pacha sp. nov. female MUBI $14515(\mathrm{SVL}=49.7 \mathrm{~mm})$.

Paratype: MUBI 14512 (Figure 7), a subadult female from near the type locality $\left(10^{\circ} 23^{\prime} 29^{\prime \prime} \mathrm{S}\right.$, $75^{\circ} 34^{\prime} 12^{\prime \prime}$ W, $\left.1845 \mathrm{~m}\right)$.

Etymology: The specific epithet "pacha" is a female noun in Quechua language that means Earth.

Diagnosis: (1) Body robust, SVL $49.7 \mathrm{~mm}$ in a single adult female; (2) head flat, elongated, 1.4 times longer than wide; (3) ear opening distinct, slightly recessed; (4) nasals separated by frontonasal; (5) frontonasal undivided; (6) prefrontals, frontal, frontoparietals, parietals and interparietal present; (7) parietals longer than wide; (8) three supraocular; (9) 3-5 superciliar series complete; (10) nasal suture absent; (11) loreal present, in contact with the second supralabial; (12) 7-8 supralabial, four supralabials anterior to the posteroventral angle of the subocular, four infralabials; (13) 4-5 genial, all in contact; (14) collar fold present; (15) 32-35 transverse rows of dorsal, hexagonal, keeled, imbricate; (16) 19-20 transverse ventral rows, quadrangular, smooth, juxtaposed; (17) 37-38 scales around midbody; (18) lateral reduced scales at midbody in three lines; (19) limbs pentadactyl, all digits clawed; (20) 12-13 subdigital lamellae under finger IV, 18 under toe IV; (21) 6-7 femoral pores in females; (22) two preanal scales, three postanal scales; (23) tail up to 2.0 times longer than body; (24) caudals subimbricate, keeled dorsally, smooth ventrally; (25) lower palpebral disc transparent and divided in two; (26) in life the dorsum is brown with two cream dorsolateral stripe that stars over the eyes and join in the middle of the body forming a vertebral dorsal stripe that extends to the tail; lips with a cream line that extend from the third supralabial to the front of back leg; a cream lateral line between arm and leg, below the lateral line; all cream lines are bordered by continuous black spots; the venter is cream-reddish with some small scattered black spots, the gular region of head is cream-reddish with small black spots; tail is orange, with small dark spots ventrally and dorsally, and a cream-orange line laterally that begins at the back of legs and continues to tip of the tail (Figures 6 and 7). 


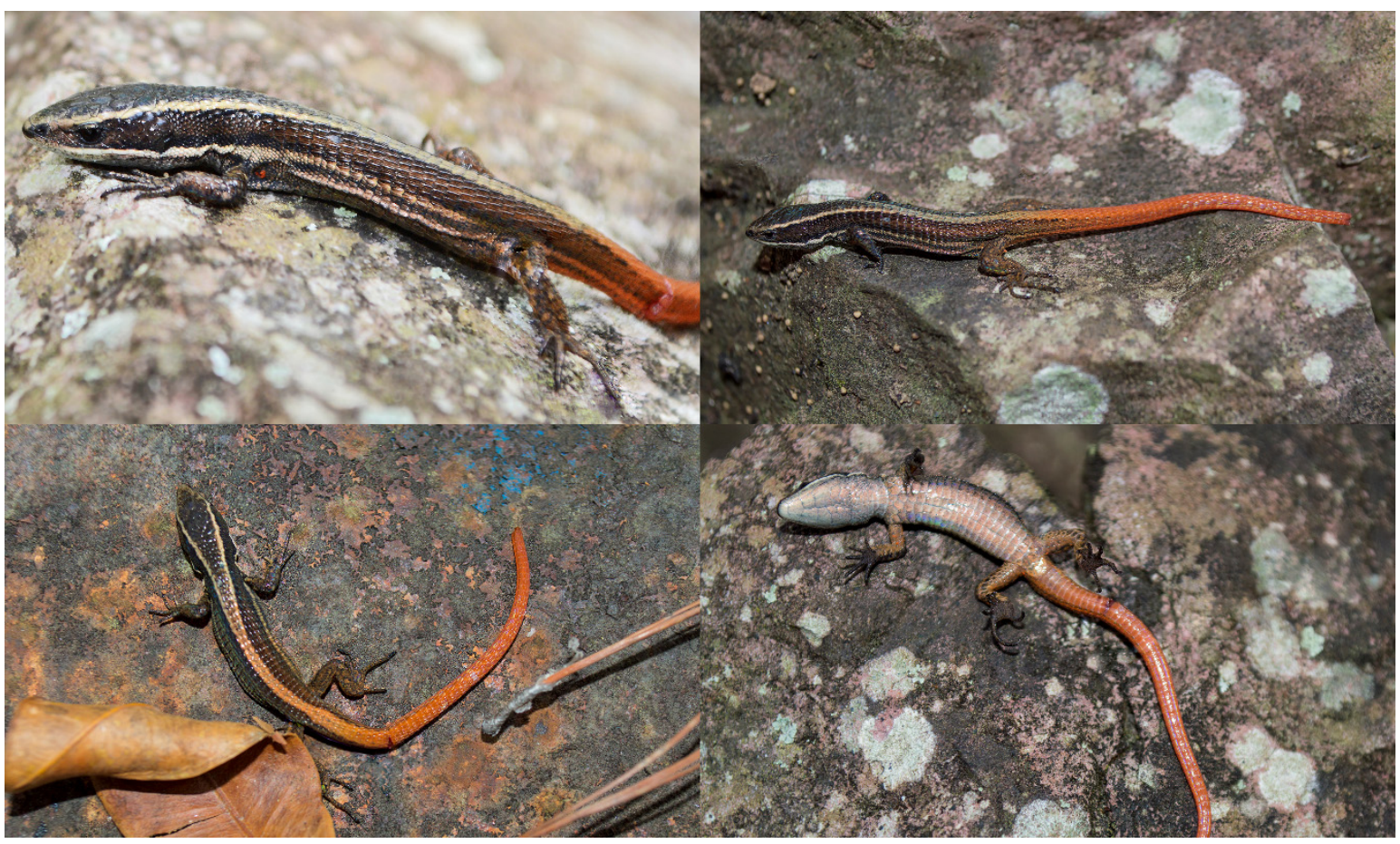

Figure 7. Live specimen of Cercosaura pacha sp. nov., subadult female MUBI 14512 (paratype, SVL = $32.4 \mathrm{~mm}$ ), from Lanturachi, near Oxapampa, Department of Pasco, Peru. Photo: Consuelo Alarcón.

Cercosaura pacha sp. nov. is similar to C. anomala, C. doanae, C. hypnoides, and C. manicata. However, C. pacha sp. nov. differs from C. anomala by having dorsal surface of neck keeled (smooth in C. anomala), six genials (4-5); from $C$. doanae by having dorsal scale of neck polygonal, keeled, and the distal edges of scales are blunt (strongly keeled, and the distal edges are pointed in C. doanae), dorsolateral stripes forming a vertebral dorsal stripe (not forming a vertebral stripe); from C. hypnoides by having loreal scales in contact with supralabials (not in contact with supralabias), eight longitudinal ventral scales (six), dorsal scales of neck polygonals (rounded); from C. manicata by having three postoculars (four in C. manicata), three suboculars (4-5), eight longitudinal ventral scales (six). Furthermore, C. pacha sp. nov. differs from C. anordosquama, C. argulus, C. bassleri, C. eigenmanni, C. nigroventris, C. ocellata, C. olivacea, C. oshaughnessyi, C. parkeri, C. phelpsorum, C. quadrilineata, C. schreibersii, and C. steyeri in having a clear labial bar that extends from the third supralabial to the point of insertion of the posterior limbs, and cream dorsolateral stripes that extends over the eyes and join in the middle of the body forming a single vertebral dorsal stripe that reaches the tail. Additionally, C. pacha sp. nov. can be distinguished from $C$. argulus and C. oshaughnessyi by having an undivided frontonasal (divided in C. argulus and C. oshaughnessyi); from C. anordosquama, C. bassleri, C. ocellata and C. olivacea by having the keels of the dorsal scales not organized in longitudinal rows, and eight longitudinal ventral rows (organized in longitudinal rows, and six in C. anordosquama, C. bassleri, C. ocellata and C. olivacea); from C. eigenmanni by having 37-38 scales around midbody (26-32 in C. eigenmanni); from $C$. nigroventris by having 37-38 scales around the midbody (40-44 in C. nigroventris), dorsal scales strongly keeled (weakly keeled in C. nigroventris); from C. parkeri by having 37-38 scales around the mid-body (24-30 in C. parkeri); from C. phelpsorum by having dorsal scales strongly keeled (weakly keeled in C. phelpsorum); from C. quadrilineata by having eight longitudinal ventral scales (four in C. quadrilineata); from C. schreibersii by having eight longitudinal ventral scales (six in C. schreibersii); from C. steyeri by having eight longitudinal rows of ventral scales (four in C. steyeri) and 37-38 scales around midbody (17).

Description of the holotype (MUBI 14515): Adult female, SVL $=49.7 \mathrm{~mm}$, tail length $=98.1 \mathrm{~mm}$; head scales with some rugosities; rostral scale wider $(2.3 \mathrm{~mm})$ than tall $(1.2 \mathrm{~mm})$, meeting supralabials on either side at above the height of supralabials, and becoming higher medially, in contact with frontonasal, 
nasal, and first supralabials; frontonasal polygonal with blunt edges, wider than longer, widest at the back, in contact with rostral, nasals, loreals, and prefrontals; prefrontals paired, polygonal, in contact with frontonasal, loreal, first superciliar, first supraocular, and frontal; frontal longer than wide, polygonal, in contact with first and second supraocular, and frontoparietals; frontoparietals polygonal, in contact with the frontal, second and third supraoculars, parietals, and interparietal; three supraoculars, all in contact with superciliaries, frontal, frontoparietals, parietal, and postocular; interparietal longer than wide, heptagonal, in contact with frontoparietals anteriorly, with parietal laterally, and with postparietals posteriorly; parietals polygonal, anteriorly in contact with frontoparietals, third supraocular, and postocular, laterally in contact with interparietals and temporals, and posteriorly postparietals; three postparietals, smaller than parietals, the mid postparietal is smaller than laterals postparietals. Nasal undivided, longer than high, in contact with first and second supralabials; loreal present, in contact with second supralabials, nasal, first superciliar, and frenocular; four superciliars, the first expanded onto surface of head; frenocular trapezoidal, in contact with second and third supralabials, infraocular, subocular, and loreal scales; palpebral disc divided in two semitransparent scales; three suboculars; three postoculars; temporals with keeled and smooth scales (the big scales smooth and the small scales keeled), and polygonal; four supralabials anterior to the posteroventral angle of the subocular. Mental wider $(2.3 \mathrm{~mm})$ than long $(1.5 \mathrm{~mm})$, in contact with first infralabial and postmental posteriorly; postmental single, polygonal, in contact with first and second infralabial, and first pairs of genials; five genials, all in contact, on the left side two and on the right three, in contact with second, third, and fourth infralabials; 35 pregulars irregularly distributed, and small in the mid; seven rows of gular scales including the collar, the middle scales enlarged; collar fold distinct, formed by large scales; lateral neck scales round, upper scales keeled, and lower scales smooth; dorsal neck scales polygonal and keeled. Dorsal hexagonal, longer tan wide, juxtaposed, strongly keeled, in 35 transverse rows; 30 longitudinal dorsal scale rows at midbody; lateral scale series slightly smaller than dorsal; reduced scales at limb insertion regions; 20 transverse ventral scale rows; eight longitudinal ventral scale rows at midbody; four anterior preanal plate scales (the lateral scales are smaller), three posterior preanal plate scales; scales on tail rectangular, juxtaposed, and smooth. Limbs pentadactyl; digits clawed; dorsal brachial scales polygonal, imbricate, and slightly keeled; ventral brachial scales small, rounded, and smooth; dorsal antebrachial scales polygonal, subequal in size, smooth, and imbricate; ventral antebrachial small, subimbricate, and rounded; dorsal manus scales polygonal, smooth, and subimbricate; palmar scales small, rounded, and domelike; dorsal scale on fingers smooth, quadrangular, imbricate, four on finger I, six on II, eight on III, nine on IV, and five on $\mathrm{V}$; scales on anterodorsal surface of thigh large, polygonal, smooth, and sub-imbricate; scales on dorsal surface of thigh large, keeled; scales on posterior surface of thigh small, rounded, juxtaposed, and keeled; scales on ventral surface of thigh large, roundish, flat, and smooth; seven femoral pores; preanal pores absent; scales on anterior surface of crus small, polygonal, keeled, juxtaposed, and decreasing in size distally; scales on posterior surface of crus small, roundish, keeled, and sub-imbricate; scales on ventral surface of crus large, roundish, flat, and smooth; scales on dorsal of foot roundish, smooth, and imbricate; scales on ventral of foot small, rounded, juxtaposed, and domelike; scales on dorsal surface of toes quadrangular, smooth, overhanging supradigital lamellae, three on toe I, six on II, 10 on III, 12 on IV, and eight on V; fore and hind limbs overlapping when adpressed against the body.

Coloration: In preservative, the dorsal surface of the head, neck, and back is dark-brown, the dorsolateral lines are cream grayish and join at midbody to form a vertebral stripe that extends to the tail; the dorsal surface of the tail is dark brown with a dorsal stripe in the anterior part of the tail, and pale orange with some gray spots in the distal part; the lateral sides of the head and neck are blackish brown with a cream labial line that extends from the third supralabial to the anterior part of the insertion of posterior limbs; the ventral surface of the head is gray with small, irregular, brown spots; gular and ventral surfaces of the body are dark gray with cream spots around some scales; the ventral surface of the limbs and tail, are cream with some irregular, dark gray spots (Figure 6). In life, the dorsal surface of the body is brown with scattered black spots; the lateral surface of the 
body is blackish brown with black and cream spots that resemble ocelli; the ventral surface of the body is reddish cream with scattered black spots. The dorsal surface of the limbs is brown with small black spots, the ventral surface is reddish cream with small black spots. The dorsal and ventral surfaces of the tail are orange, and the ventral surfaces of the limbs are similar to the ventral surface of the body (Figures 6 and 7).

Variation: Table 5 summarizes morphometric characters and pholidosis.

Distribution and natural history: Cercosaura pacha sp. nov. inhabits montane forests on the eastern slopes of Cordillera de los Andes, Department of Pasco, central Peru, between 1845-1986 m a.s.l (Figure 1). We captured two specimens using pitfall traps set up for 10 days at the type locality (Figure 8).

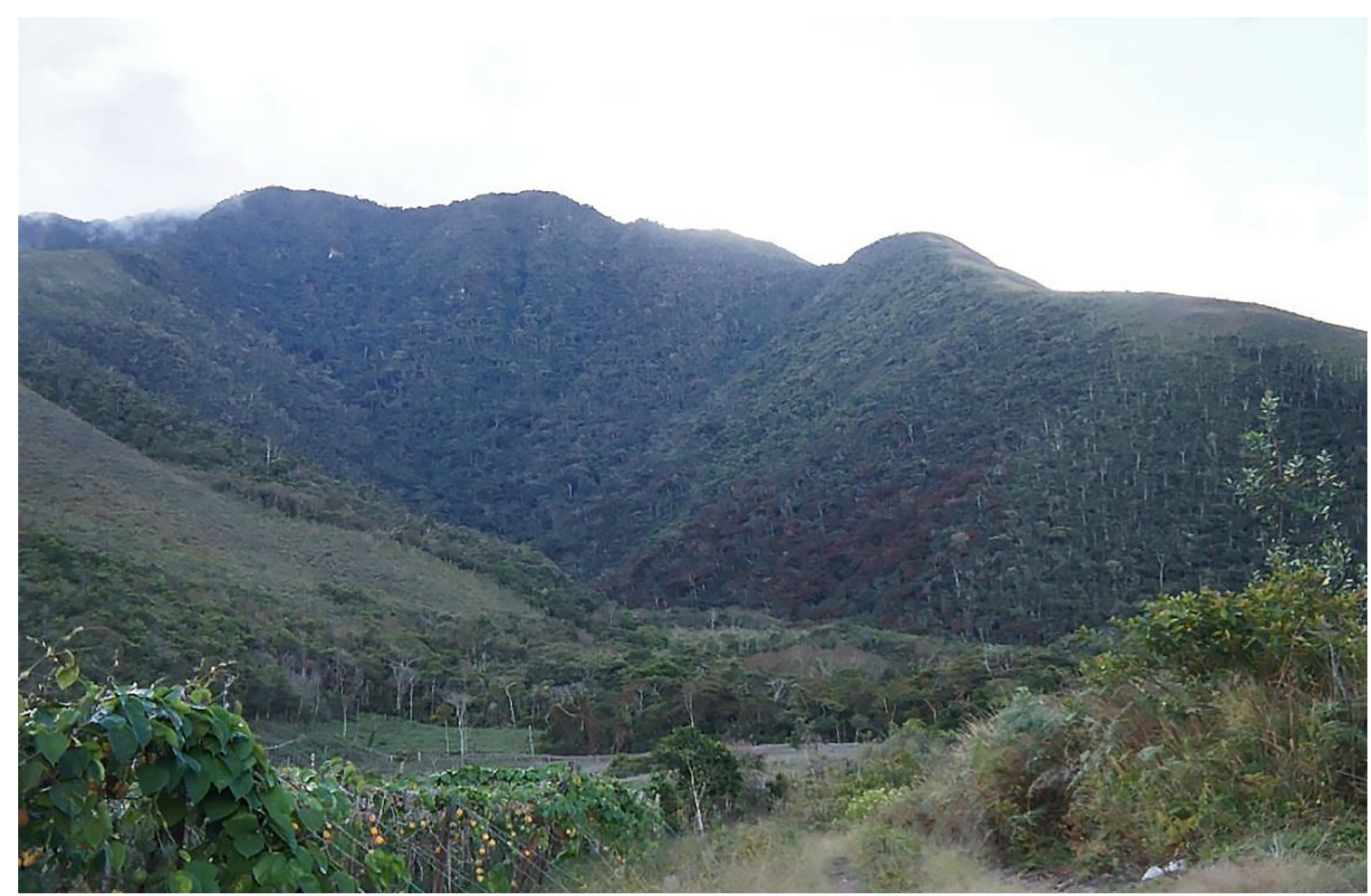

Figure 8. Type locality of Cercosaura pacha sp. nov, montane forest of Lanturachi, near Oxapampa, Department of Pasco, Peru. Photo: Consuelo Alarcón.

Taxonomic status of Cercosaura manicata boliviana

Cercosaura manicata boliviana is considered a subspecies of Cercosaura manicata, which is distributed from southeastern Peru to central Bolivia [30]. Werner [54] described C. manicata boliviana as Prionodactylus bolivianus based on a specimen (Muséum national d'Histoire naturelle, MNHN 00.4) collected in the montane forests of Bolivia (Chacó). Subsequently, P. bolivianus and P. ockendeni were considered synonyms of Prionodactylus manicatus, but both with subspecies status [30]. Finally, according to a phylogenetic study based on morphological data, P. manicatus bolivianus was transferred to the genus Cercosaura [18]. Echevarría et al. [16] and Uzzell [30] observed clear differences between both subspecies; however, only Echevarría et al. [16] considered this taxon as a putative separate species, and highlighted the need for genetic evidence.

The genus Prionodactylus was erected by O'Shaughnessy [55], and the type species was Prionodactylus manicatus. However, P. manicatus was transferred to the genus Cercosaura, and Prionodactylus was invalidated and considered as a synonym of Cercosaura [18].

According to the molecular evidence obtained in this study using two specimens from southern Peru (Figure 9), Cercosaura manicata boliviana is the sister lineage of the genus Potamites; therefore, 
it should be excluded from Cercosaura. However, the taxonomic assignation of Cercosaura manicata boliviana remains uncertain, because the genus Prionodactylus (original genus) is no longer valid. We could assign this species to Potamites, but external morphological characters and ecological traits do not support this taxonomic change. Potamites is a genus of lizards strongly associated with aquatic ecosystems [20], whereas the individuals of "Cercosaura manicata boliviana" have semi-arboreal habits. Thus, we propose to maintain the name "Cercosaura manicata boliviana" incertae sedis until a dedicated study can ascertain its phylogenetic relationships.

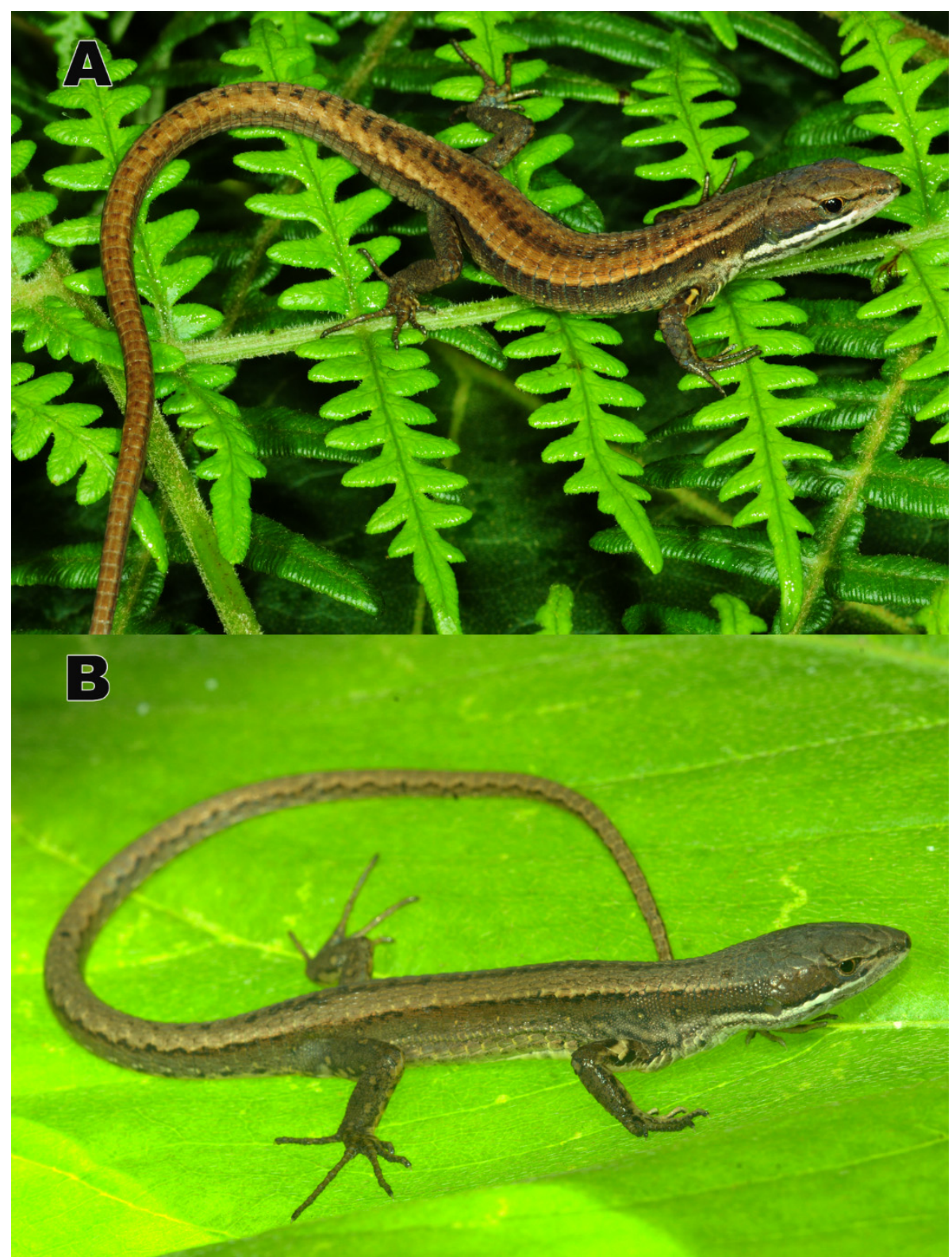

Figure 9. Live specimen of "Cercosaura manicata boliviana"; (A) adult male CORBIDI 16500 $(\mathrm{SVL}=42.5 \mathrm{~mm})$, from near San Pedro, Kosñipata Valley, Department of Cusco, Peru; (B) CORBIDI 18716 (SVL $=44.1 \mathrm{~mm}$ ), from Santo Domingo, District of Limbani, Province of Sandia, Department of Puno, Peru. Photo: Alessandro Catenazzi.

In conclusion, the molecular, ecological, and morphological evidence support the hypothesis that "Cercosaura manicata boliviana is a separate species and a new lineage, which is sister to lizards of the genus Potamites. Future studies should ascertain the relationship of this incertae sedis with Potamites, and determine whether P. bolivianus and P. ockendeni are conspecifics or separate species. 


\section{Discussion}

Our molecular and morphological evidence solves the taxonomy of Cercosaura anomala, reveals "Cercosaura manicata boliviana" as incertae sedis, and supports the description of a new species of Cercosaura from the Andes of Peru. Despite a complex taxonomic history, genetic data have supported recent changes in the systematics and taxonomy of cercosaurine lizards, increasing our understanding of their evolutionary history (e.g., $[6,10,12,19,27,53])$. However, genetic studies are still incomplete, and many genera and species are pending review and broader sampling of genetic sequences $[6,10,12]$.

The ML topology obtained in this study using concatenated sequences of mitochondrial and nuclear genes recovered the monophyly of Proctoporus and included the genus Wilsonosaura within Proctoporus. This topology contrasts with previous studies that did not support the monophyly of Proctoporus, suggesting additional studies are needed to solve the taxonomy and phylogenetic position of Proctoporus [6,11,12,51,52]. Moreover, our study considered 129 terminals and addressed the taxonomy and phylogenetic relationships of the three species of Cercosaura (Cercosaura anomala, "Cercosaura manicata boliviana", and Cercosaura pacha sp. nov.).

We designated a neotype for Cercosaura anomala, a designation carried out in accordance with article 75.3 of the ICZN, based on a specimen collected in Puente Ruinas, inside the Historical Sanctuary of Machupicchu, Department of Cusco, Peru. The designation of HSM as the type locality of $C$. anomala, and associated genetic data we provided in this work, are important because they will facilitate future taxonomic, phylogenetic, ecological, and evolutionary studies. Moreover, with the generic allocation of $C$. anomala and the description of a new species, we increase the diversity of the genus Cercosaura, which now contains 18 species.

In the original description of Cercosaura anomala, Müller [21] observed the small size of the prefrontal scales, and the separation between them, stating that these could be rudimentary. Among the material examined in this study, all specimens have large and attached prefrontals, except a subadult female (MUBI 819) with separate prefrontal scales. Variation in the form of prefrontals, and other characters, occurs in different species of gymnophthalmid lizards such as Pholidobolus vertebralis [24], Proctoporus spinalis [23], P. machupicchu [56], and P. laudhanae [57]. The high cryptic diversity, and the variation observed in the characters used in taxonomy of these lizards warn us that generic assignments and the description of new species should be undertaken with caution, and if possible, supported by genetic evidence $[10,12,20,29]$.

Despite the similarity of coloration patterns of Cercosaura anomala with species of Pholidobolus, and "C. manicata boliviana" with C. manicata, both species were not nested in their designated genera. This result shows that external morphological characters in gymnophthalmid lizards can converge in coloration, and pholidosis $[10,12,20,52]$. Examples of convergence are the body shape of six divergent lineages of semi-aquatic lizards of the genera Centrosaura, Echinosaura, Gelanesaurus, Neusticurus, Potamites, and Rheosaurus, which share similar body shape ("cocodrile like morphology"), presence of irregulars scales on the back, and a laterally flattened tail that aids in water locomotion [31,58]; body elongations in Anotosaura, Bachia, Calyptommatus, Heterodactylus, Nothobachia, and Scriptosaura, [32,59]; legs reduction in Bachia, Colobosaura, and Scriptosaura [9,32,60]; and external ear loss in Antonosaura, Bachia, Heterodactylus, Nothobachia, Rachisaurus brachylepis, and Scriptosaura catimbau [32,60]. In light of high frequency of evolutionary convergence, it is expected that lizards of the genera Cercosaura, Pholidobolus, Macropholidus, and "Cerosaura manicata boliviana" share similarities in their coloration patterns. Future evolutionary studies will further elucidate evolutionary convergence in these lizards.

Supplementary Materials: The following are available online at http://www.mdpi.com/1424-2818/12/9/361/s1: Table S1: Vouchers and accession number codes of taxa included in this study available from GenBank. Figures S1 and S2: Mitochondrial and nuclear maximum likelihood trees respectively showing the phylogenetic relationships of Cercosaura, and other gymnophthalmid lizards.

Author Contributions: Conceptualization: L.M., J.C.C., C.C. and A.C.; methodology, L.M., C.C. and A.C.; software, L.M., C.C., C.A., and A.C.; validation, L.M., J.C.C., C.C., C.A., C.Y.S. and A.C.; formal analysis, L.M. 
and A.C.; investigation, L.M., J.C.C., C.C., C.A., C.Y.S., and A.C.; resources, A.C.; data curation, L.M., J.C.C., C.C., C.A., C.Y.S., and A.C.; writing-original draft preparation, L.M., C.C. and A.C.; writing-review and editing, L.M., J.C.C., C.C., C.A., C.Y.S. and A.C.; visualization, L.M., C.C. and A.C.; supervision, C.C. and A.C.; project administration, L.M. and A.C.; funding acquisition, L.M. and A.C. All authors have read and agreed to the published version of the manuscript.

Funding: The Asociación para la Conservación de la Cuenca Amazónica (ACCA) provided logistical support at Urusayhua and Tucantinas in Departament of Cusco, Peru.

Acknowledgments: We thank Evaristo López (MUSA), Pablo Venegas (CORBIDI), and MUBI staff for allowing access to their respective herpetological collections during this study; Juan Carlos Chávez-Arribasplata (CORBIDI) for allowing us to use his photographs (Figure 3C,D); Tiffany M. Doan and an anonymous reviewer for their comments and suggestions that improved this manuscript.

Conflicts of Interest: The authors declare no conflict of interest.

\section{Appendix A. Specimens Examined}

Cercosaura anomala-Peru: Department of Cusco: Province of Urubamba, District of Machupicchu, sector Puente Ruinas (MUBI 640, 641, 817, 5277); Province of La Convención, District of Santa Ana, sector Urusayhua (MUBI 13626), sector Tucantinas (MUBI 13328, 13529); District of Maranura (MUSA 4537); District of Quellouno (MUBI 16169).

Cercosaura manicata-Peru: Department of Cusco, Province of La Convención, District of Kimbiri, sector Pomoreni (MUBI 6789) and Pichari (MUBI 15734, 15735, 15736).

Cercosaura pacha sp. nov.-Peru: Department of Pasco, Province of Oxapampa, District of Huancabamba, sector Lanturachi (MUBI 14512, 14515).

Cercosaura sp.-Peru: Department of Cusco, Province of Quispicanchi, District of Camanti, sector Sirigua (MUBI 5881).

"Cercosaura manicata boliviana"-Peru: Department of Puno: Province of Paucartambo, District of Kosñipata, Parque Nacional del Manu, Trocha Unión (MUBI 5045), sector San Pedro (CORBIDI 16500); Departament of Puno, Province of Carabaya, sector Gallucunka (MUBI 4657), sector Ollachea (MUBI 11575), Province of Sandia, District of Limbani, Santo Domingo (CORBIDI 18716).

\section{References}

1. Myers, N.; Mittermeier, R.A.; Mittermeier, C.G.; Da Fonseca, G.A.; Kent, J. Biodiversity hotspots for conservation priorities. Nature 2000, 403, 853-858. [CrossRef] [PubMed]

2. Timms, J.; Chaparro, J.C.; Venegas, P.J.; Salazar-Valenzuela, D.; Scrocchi, G.; Cuevas, J.; Leynaud, G.; Carrasco, P. A new species of pitviper of the genus Bothrops (Serpentes: Viperidae: Crotalinae) from the Central Andes of South America. Zootaxa 2019, 4656, 99-120. [CrossRef] [PubMed]

3. Tejedor, A.; Calatayud, G. Eleven new scaly tree ferns (Cyathea: Cyatheaceae) from Peru. Am. Fern J. 2017, 107, 156-191. [CrossRef]

4. Rodríguez, L.O.; Mamani, L. A new species of Petracola (Squamata: Gymnophthalmidae) from Río Abiseo National Park, San Martín, Peru. Amphib. Reptil. Conserv. 2020, 14, 140-146.

5. Lehr, E.; Moravec, J.; Lundberg, M.; Koehler, G.; Catenazzi, A.; Smid, J. A new genus and species of arboreal lizard (Gymnophthalmidae: Cercosaurinae) from the eastern Andes of Peru. Salamandra 2019, 55, 1-13.

6. Moravec, J.; Šmíd, J.; Štundl, J.; Lehr, E. Systematics of Neotropical microteiid lizards (Gymnophthalmidae, Cercosaurinae), with the description of a new genus and species from the Andean montane forests. ZooKeys 2018, 774, 105-139. [CrossRef]

7. Chavez, G.; Catenazzi, A.; Venegas, P.J. A new species of arboreal microteiid lizard of the genus Euspondylus (Gymnophtalmidae: Cercosaurinae) from the Andean slopes of central Peru with comments on Peruvian Euspondylus. Zootaxa 2017, 4350, 301-316. [CrossRef]

8. Mamani, L.; Goicoechea, N.; Chaparro, J.C. A new species of Andean lizard Proctoporus (Squamata: Gymnophthalmidae) from montane forest of the Historic Sanctuary of Machu Picchu, Peru. Amphib. Reptil. Conserv. 2015, 9, 1-11. 
9. Goicoechea, N.; Padial, J.M.; Chaparro, J.C.; Castroviejo-Fisher, S.; De la Riva, I. A taxonomic revision of Proctoporus bolivianus Werner (Squamata: Gymnophthalmidae) with the description of three new species and resurrection of Proctoporus lacertus Stejneger. Am. Mus. Novit. 2013, 3786, 1-32. [CrossRef]

10. Goicoechea, N.; Padial, J.M.; Chaparro, J.C.; Castroviejo-Fisher, S.; De la Riva, I. Molecular phylogenetics, species diversity, and biogeography of the Andean lizards of the genus Proctoporus (Squamata: Gymnophthalmidae). Mol. Phylogenet. Evol. 2012, 65, 953-964. [CrossRef]

11. Torres-Carvajal, O.; Lobos, S.E.; Venegas, P.J. Phylogeny of Neotropical Cercosaura (Squamata: Gymnophthalmidae) lizards. Mol. Phylogenet. Evol. 2015, 93, 281-288. [CrossRef] [PubMed]

12. Torres-Carvajal, O.; Lobos, S.E.; Venegas, P.J.; Chávez, G.; Aguirre-Peñafiel, V.; Zurita, D.; Echevarría, L.Y. Phylogeny and biogeography of the most diverse clade of South American gymnophthalmid lizards (Squamata, Gymnophthalmidae, Cercosaurinae). Mol. Phylogenet. Evol. 2016, 99, 63-75. [CrossRef] [PubMed]

13. Sturaro, M.J.; Rodrigues, M.T.; Colli, G.R.; Knowles, L.L.; Avila-Pires, T.C. Integrative taxonomy of the lizards Cercosaura ocellata species complex (Reptilia: Gymnophthalmidae). Zool. Anz. 2018, 275, 37-65. [CrossRef]

14. Uetz, P.; Freed, P.; Hošek, J. (Eds.) The Reptile Database. Available online: http://www.reptile-database.org (accessed on 14 April 2020).

15. Sturaro, M.J.; Avila-Pires, T.C.S.; Rodrigues, M.T. Molecular phylogenetic diversity in the widespread lizard Cercosaura ocellata (Reptilia: Gymnophthalmidae) in South America. Syst. Biodivers. 2017, 15, 532-540. [CrossRef]

16. Echevarría, L.Y.; Barboza, A.C.; Venegas, P.J. A new species of montane gymnophthalmid lizard, genus Cercosaura (Squamata: Gymnophthalmidae), from the Amazon slope of northern Peru. Amphib. Reptil. Conserv. 2015, 9, 34-44.

17. Doan, T.M.; Lamar, W.W. A new montane species of Cercosaura (Squamata: Gymnophthalmidae) from Colombia, with notes on the distribution of the genus. Zootaxa 2012, 3565, 44-54. [CrossRef]

18. Doan, T.M. A new phylogenetic classification for the Gymnophthalmid genera Cercosaura, Pantodactylus and Prionodactylus (Reptilia: Squamata). Zool. J. Linnean Soc. 2003, 137, 101-115. [CrossRef]

19. Castoe, T.A.; Doan, T.M.; Parkinson, C.L. Data partitions and complex models in Bayesian analysis: The phylogeny of gymnophthalmid lizards. Syst. Biol. 2004, 53, 448-469. [CrossRef]

20. Doan, T.M.; Castoe, T.A. Phylogenetic taxonomy of the Cercosaurini (Squamata: Gymnophthalmidae), with new genera for species of Neusticurus and Proctoporus. Zool. J. Linnean Soc. 2005, 143, 405-416. [CrossRef]

21. Müller, L. Neue oder seltene Reptilien und Batrachier der Zoologischen Sammlung des bayrischen Staates. Zool. Anz. 1923, 57, 49-61.

22. Franzen, M.; Glaw, F. Type catalogue of reptiles in the Zoologische Staatssammlung München. Spixiana 2007, 30, 201-274.

23. Köhler, G.; Lehr, E. Comments on Euspondylus and Proctoporus (Squamata: Gymnophthalmidae) from Peru, with the description of three new species and a key to the Peruvian species. Herpetologica 2004, 60, 501-518. [CrossRef]

24. Doan, T.M.; Cusi, J.C. Geographic distribution of Cercosaura vertebralis O'Shaughnessy, 1879 (Reptilia: Squamata: Gymnophthalmidae) and the status of Cercosaura ampuedai (Lancini, 1968). Check List 2014, 10, 1195-1200. [CrossRef]

25. Montanucci, R.R. Systematics and evolution of the Andean lizard genus Pholidobolus (Sauria: Teiidae). Univ. Kans. Mus. Nat. Hist. Misc. Publ. 1973, 59, 1-52.

26. Reeder, T.W. A new species of Pholidobolus (Squamata: Gymnophthalmidae) from the Huancabamba depression of northern Peru. Herpetologica 1996, 52, 282-289.

27. Torres-Carvajal, O.; Mafla-Endara, P. Evolutionary history of Andean Pholidobolus and Macropholidus (Squamata: Gymnophthalmidae) lizards. Mol. Phylogenet. Evol. 2013, 68, 212-217. [CrossRef]

28. Hurtado-Gómez, J.P.; Arredondo, J.C.; Sales-Nunes, P.M.; Daza, J.M. A new species of Pholidobolus (Squamata: Gymnophthalmidae) from the paramo ecosystem in the northern Andes of Colombia. S. Am. J. Herpetol. 2018, 13, 271-286. [CrossRef]

29. Parra, V.; Nunes, P.M.S.; Torres-Carvajal, O. Systematics of Pholidobolus lizards (Squamata, Gymnophthalmidae) from southern Ecuador, with descriptions of four new species. Zookeys 2020, 954, 109-156. [CrossRef] 
30. Uzzell, T.M. A revision of lizard of the genus Prionodactylus, with a new genus for P. leucotictus and notes on the genus Euspondylus (Sauria, Teiidae). Postilla 1973, 150, 1-67. [CrossRef]

31. Kocher, T.D.; Thomas, W.K.; Meyer, A.; Edwards, S.V.; Pääbo, S.; Villablanca, F.X.; Wilson, A.C. Dynamics of mitochondrial DNA evolution in animals: Amplification and sequencing with conserved primers. Proc. Natl. Acad. Sci. USA 1989, 86, 6196-6200. [CrossRef]

32. Pellegrino, K.C.M.; Rodrigues, M.T.; Yonenaga-Yassuda, Y.; Sites, J.W. A molecular perspective on the evolution of microteiid lizard (Squamata, Gymnophthalmidae), and a new classification for the family. Biol. J. Linnean Soc. 2001, 74, 315-338. [CrossRef]

33. Blair, C.; Méndez de La Cruz, F.R.; Ngo, A.; Lindell, J.; Lathrop, A.; Murphy, R.W. Molecular phylogenetics and taxonomy of leaf-toed geckos (Phyllodactylidae: Phyllodactylus) inhabiting the peninsula of Baja California. Zootaxa 2009, 2027, 28-42. [CrossRef]

34. Arevalo, E.; Davis, S.K.; Sites, J.W., Jr. Mitochondrial DNA sequence divergence and phylogenetic relationships among eight chromosome races of the Sceloporus grammicus complex (Phrynosomatidae) in central Mexico. Syst. Biol. 1994, 43, 387-418. [CrossRef]

35. Saint, K.M.; Austin, C.C.; Donnellan, S.C.; Hutchinson, M.N. C-mos, a nuclear marker useful for squamate phylogenetic analysis. Mol. Phylogenet. Evol. 1998, 10, 259-263. [CrossRef] [PubMed]

36. Edgar, R.C. MUSCLE: Multiple sequence alignment with high accuracy and high throughput. Nucl. Acids Res. 2004, 32, 1792-1797. [CrossRef] [PubMed]

37. Kumar, S.; Stecher, G.; Li, M.; Knyaz, C.; Tamura, K. MEGA X: Molecular evolutionary genetics analysis across computing platforms. Mol. Biol. Evol. 2018, 35, 1547-1549. [CrossRef]

38. Maddison, W.P.; Maddison, D.R. Mesquite: A Modular System for Evolutionary Analysis. Version 3.61. 2019. Available online: http://www.mesquiteproject.org (accessed on 21 March 2020).

39. Lanfear, R.; Calcott, B.; Ho, S.Y.; Guindon, S. PartitionFinder: Combined selection of partitioning schemes and substitution models for phylogenetic analyses. Mol. Biol. Evol. 2012, 29, 1695-1701. [CrossRef]

40. Minh, B.Q.; Schmidt, H.A.; Chernomor, O.; Schrempf, D.; Woodhams, M.D.; Von Haeseler, A.; Lanfear, R. IQ-TREE 2: New models and efficient methods for phylogenetic inference in the genomic era. Mol. Biol. Evol. 2020, 37, 1530-1534. [CrossRef]

41. Hoang, D.T.; Chernomor, O.; Von Haeseler, A.; Minh, B.Q.; Vinh, L.S. UFBoot2: Improving the ultrafast bootstrap approximation. Mol. Biol. Evol. 2018, 35, 518-522. [CrossRef]

42. Barbour, T. Reptiles collected by the Yale Peruvian expedition of 1912. Proc. Acad. Nat. Sci. Phila. 1913, 65, 505-507.

43. Amaral, A. New genera and species of snakes. Proc. N. Engl. Zool. Club 1923, 8, 85-105. [CrossRef]

44. ICZN. The International Trust for Zoological Nomenclature; Natural History Museum: London, UK, $1999 ;$ p. 306.

45. Uzzell, T.M. Teiid lizards of the genus Proctoporus from Bolivia and Peru. Postilla 1970, 142, 1-39.

46. Kizirian, D.A. A review of Ecuadorian Proctoporus (Squamata: Gymnophthalmidae) with descriptions of nine new species. Herpetol. Monogr. 1996, 10, 85-155. [CrossRef]

47. Avila-Pires, T.C.S. Lizard of Brazilian Amazonia (Reptilia: Squamata); Zoologische Verhandelingen: Leiden, The Netherlands, 1995; p. 706.

48. Gorzula, S.; Senaris, J.C. Contribution to the Herpetofauna of the Venezuelan Guayana; Scientia Guaianae: Caracas, Venezuela, 1999; p. 269.

49. Soares-Barreto, D.; Martin Valdão, R.; Nogueira, C.; Potter de Castro, C.; Ferrerira, V.L.; Strüssman, C. New locality records, geographical distribution, and morphological variation in Cercosaura parkeri (Ruibal, 1952) (Squamata: Gymnophthalmidae) from western Brazil. Check List 2012, 8, 1365-1369. [CrossRef]

50. Tedesco, M.E. Una nueva especie de Pantodactylus (Squamata, Gymnophthalmidae) de la provincia de Corrientes, República de Argentina. Facena 1998, 14, 53-62.

51. Sánchez-Pacheco, S.J.; Torres-Carvajal, O.; Aguirre-Peñafiel, V.; Nunes, P.M.S.; Verrastro, L.; Rivas, G.A.; Rodrigues, M.T.; Grant, T.; Murphy, R.W. Phylogeny of Riama (Squamata: Gymnophthalmidae), impact of phenotypic evidence on molecular datasets, and the origin of the Sierra Nevada de Santa Marta endemic fauna. Cladistics 2018, 34, 260-291. [CrossRef]

52. Vásquez-Restrepo, J.D.; Ibáñez, R.; Sánchez-Pacheco, S.J.; Daza, J.M. Phylogeny, taxonomy and distribution of the Neotropical lizard genus Echinosaura (Squamata: Gymnophthalmidae), with the recognition of two new genera in Cercosaurinae. Zool. J. Linnean Soc. 2019, 189, 287-314. [CrossRef] 
53. Fisher-Reid, M.C.; Wiens, J.J. What are the consequences of combining nuclear and mitochondrial data for phylogenetic analysis? Lessons from Plethodon salamanders and 13 other vertebrate clades. BMC Evol. Biol. 2011, 11, 300. [CrossRef]

54. Werner, F. Beschreibung neuer Reptilien und Batrachier. Zool. Anz. 1899, 22, 479-484.

55. O'Shaughnessy, A.W.E. An Account of the Collection of Lizards made by Mr. Buckley in Ecuador, and now in the British Museum, with descriptions of the new Species. Proc. Zool. Soc. Lond. 1881, 49, 227-245. [CrossRef]

56. Díaz, M.I.; Ttito, A.; Mamani, L. Una nueva localidad y reexaminación de la serie tipo de la lagartija Andina de Machu Picchu Proctoporus machupicchu Mamani, Goicoechea y Chaparro, 2015 (Squamata: Gymnophthalmidae). Rev. Peru. Biol. 2019, 26, 503-508. [CrossRef]

57. Chávez, G.; Chávez-Arribasplata, J.C. Distribution and natural history notes on the Peruvian lizard Proctoporus laudahnae (Squamata: Gymnophthalmidae). Phyllomedusa J. Herpetol. 2016, 15, 147-154. [CrossRef]

58. Marques-Souza, S.; Prates, I.; Fouquet, A.; Camacho, A.; Kok, P.J.; Nunes, P.M.; Vechio, F.D.; Recorder, R.S.; Mejia, N.; Junior, M.T.; et al. Reconquering the water: Evolution and systematics of South and Central American aquatic lizards (Gymnophthalmidae). Zool. Scr. 2018, 47, 255-265. [CrossRef]

59. Grizante, M.B.; Brandt, R.; Kohlsdorf, T. Evolution of body elongation in gymnophthalmid lizards: Relationships with climate. PLoS ONE 2012, 7, e49772. [CrossRef] [PubMed]

60. Rodrigues, M.T.; Santos, E.M.D. A new genus and species of eyelid-less and limb reduced gymnophthalmid lizard from northeastern Brazil (Squamata, Gymnophthalmidae). Zootaxa 2008, 1873, 50-60. [CrossRef]

(C) 2020 by the authors. Licensee MDPI, Basel, Switzerland. This article is an open access article distributed under the terms and conditions of the Creative Commons Attribution (CC BY) license (http://creativecommons.org/licenses/by/4.0/). 